\title{
Debris Flows Occurrence in the Semiarid Central Andes under Climate Change Scenario
}

\author{
Stella M. Moreiras ${ }^{1,2, *}$, , Sergio A. Sepúlveda ${ }^{3,4}{ }^{\oplus}$, Mariana Correas-González ${ }^{1} \oplus$, Carolina Lauro ${ }^{1}{ }^{\oplus}$, \\ Iván Vergara ${ }^{5}$, Pilar Jeanneret ${ }^{1}$, Sebastián Junquera-Torrado ${ }^{1}{ }^{\mathbb{D}}$, Jaime G. Cuevas ${ }^{6}$, Antonio Maldonado ${ }^{6,7}$, \\ José L. Antinao ${ }^{8}$ and Marisol Lara ${ }^{3}$
}

1 Instituto Argentino de Nivología, Glaciología \& Ciencias Ambientales, CONICET, Mendoza M5500, Argentina; mcorreas@mendoza-conicet.gob.ar (M.C.-G.); clauro@mendoza-conicet.gob.ar (C.L.); pjeanneret@mendoza-conicet.gob.ar (P.J.); sjunquera@mendoza-conicet.gob.ar (S.J.-T.)

2 Catedra de Edafología, Facultad de Ciencias Agrarias, Universidad Nacional de Cuyo, Mendoza M5528AHB, Argentina

3 Departamento de Geología, Facultad de Ciencias Físicas y Matemáticas, Universidad de Chile, Santiago 8320000, Chile; sesepulv@ing.uchile.cl (S.A.S.); mlara.uchile@gmail.com (M.L.)

4 Instituto de Ciencias de la Ingeniería, Universidad de O'Higgins, Rancagua 2820000, Chile

5 Grupo de Estudios Ambientales-IPATEC, San Carlos de Bariloche 8400, Argentina; ivergara@comahue-conicet.gob.ar

6 Centro de Estudios Avanzados en Zonas Áridas (CEAZA), Universidad de La Serena, Coquimbo 1780000, Chile; jxcuevas@ceaza.cl (J.G.C.); antonio.maldonado@ceaza.cl (A.M.)

7 Departamento de Biología Marina, Universidad Católica del Norte, Larrondo 1281, Coquimbo 1780000, Chile 8 Indiana Geological and Water Survey, Indiana University, Bloomington, IN 47404, USA; jantinao@iu.edu

* Correspondence: moreiras@mendoza-conicet.gob.ar; Tel.: +54-26-1524-4256

Citation: Moreiras, S.M.; Sepúlveda, S.A.; Correas-González, M.; Lauro, C.; Vergara, I.; Jeanneret, P.;

Junquera-Torrado, S.; Cuevas, J.G.; Maldonado, A.; Antinao, J.L.; et al. Debris Flows Occurrence in the Semiarid Central Andes under Climate Change Scenario. Geosciences 2021, 11, 43. https://doi.org/ 10.3390 /geosciences 11020043

Received: 7 November 2020

Accepted: 14 January 2021

Published: 22 January 2021

Publisher's Note: MDPI stays neutral with regard to jurisdictional claims in published maps and institutional affiliations.

Copyright: (c) 2021 by the authors. Licensee MDPI, Basel, Switzerland. This article is an open access article distributed under the terms and conditions of the Creative Commons Attribution (CC BY) license (https:// creativecommons.org/licenses/by/ $4.0 /)$.
Abstract: This review paper compiles research related to debris flows and hyperconcentrated flows in the central Andes $\left(30^{\circ}-33^{\circ} \mathrm{S}\right)$, updating the knowledge of these phenomena in this semiarid region. Continuous records of these phenomena are lacking through the Andean region; intense precipitations, sudden snowmelt, increased temperatures on high relief mountain areas, and permafrost degradation are related to violent flow discharges. Documented catastrophic consequences related to these geoclimatic events highlight the need to improve their understanding in order to prepare the Andean communities for this latent danger. An amplified impact is expected not only due to environmental changes potentially linked to climate change but also due to rising exposure linked to urban expansion toward more susceptible or unstable areas. This review highlights as well the need for the implementation of preventive measures to reduce the negative impacts and vulnerability of the Andean communities in the global warming context.

Keywords: natural hazard; permafrost; feeding sediments; global warming

\section{Introduction}

As in other high mountain ranges around the world, landslide processes are widespread in the Central Andes of Chile and Argentina [1-5]. Geomorphological studies have described paleo-landslides in the Central Andes [6-9]; however, studies of the most dangerous and impacting events such as debris flows are rare. These sudden events have generated many fatalities, destruction along international transportation corridors, road damages, house destructions, traffic interruptions, infrastructures damages, and complications on drinking water supply with underestimated regional economical loses [10-12]. Despite the high economic costs, the hydraulic characterization of these destructive events is not well known, thus preventing the adoption of adequate structural preventive measures for mitigating risks. At the same time, non-systematic monitoring of these phenomena impedes evaluation on the recurrence or frequency of events. The focus of attention on 
emergencies instead of preparedness or the adoption of preventive measures is the most common approach. Landslide hazard and risk assessment studies are starting to gradually be included in land-use planning of government offices.

Current climate trends and future projections show in addition to temperature rise a decrease in winter rainfall [13], increased summer rainfall (this is better documented in the Argentine side), and a rise in the torrential nature of storms [14]. Snow precipitation has been reduced since 2010 on the Central Andes [15,16]. This period of 10 consecutive dry years has been called around the region the Mega Drought [16]. All these natural environmental conditions are correlated with landslide activity and the occurrence of debris flows of the Central Andes, showing a positive temporal trend [7,17-19]. Global warming has led to an increase in the elevation of the $0{ }^{\circ} \mathrm{C}$ isotherm [20] inducing glacier retreat, which enhances the debutressing of hillslopes and mass wasting processes that might result in a double phenomenon. First, larger amounts of erodible material are generated and available for remobilization as flows; second, new glacial lakes are formed, constituting unstable water reservoirs in high mountain areas [21]. At the same time, growing pressure from human activities is expanding toward unstable areas and there is a continuing high rate of deforestation due to logging, burning, and development, which are factors that increase severity of debris flows activity. Assessment of debris flow hazard is fundamental to develop preventive measures that reduce the severity of this potential natural hazard.

This review gathers research conducted on debris flows and hyperconcentrated flows in the Central Andes $\left(30^{\circ}-33^{\circ} \mathrm{S}\right)$, which is a region underrepresented in the international literature. Local reports and articles written in Spanish were included in this work to bring these cases to a broader audience. The main scope of our paper is to update the knowledge of these phenomena in this semiarid region trying to understand their behavior in the context of documented climate change [20]. Furthermore, this review highlights research gaps and a certain lack of local measurement data that are limiting a better understanding of debris flows in the Central Andes.

\section{Semiarid Central Andes}

The Central or Subtropical Andes (CA) extend from $31^{\circ}$ to $35^{\circ}$ south latitude comprising Western Chilean and Eastern Argentinean hillslopes [22]. The extent of CA has been defined differently [23], but this range system is considered as a transition zone between the hyperarid and semiarid conditions of the northern arid Andes and the southern humid Patagonian Andes. This climate transition segment is forced by the Arid Diagonal that separates summer precipitation patterns driven from the tropics, from winter precipitation driven by the westerlies to the south [24] (Figure 1). The summer precipitation cycle east of the Andes is originated by convective storms influenced by continental air masses [25,26], whereas winter precipitation on the highest elevation of the Andes is a consequence of the interaction between the moisture fluxes coming from the synoptic systems of the middle latitudes of the South Pacific, the topography of the Andes, the occurrence of cut-off low during the cold season [27], and the passage of cold fronts [28]. 


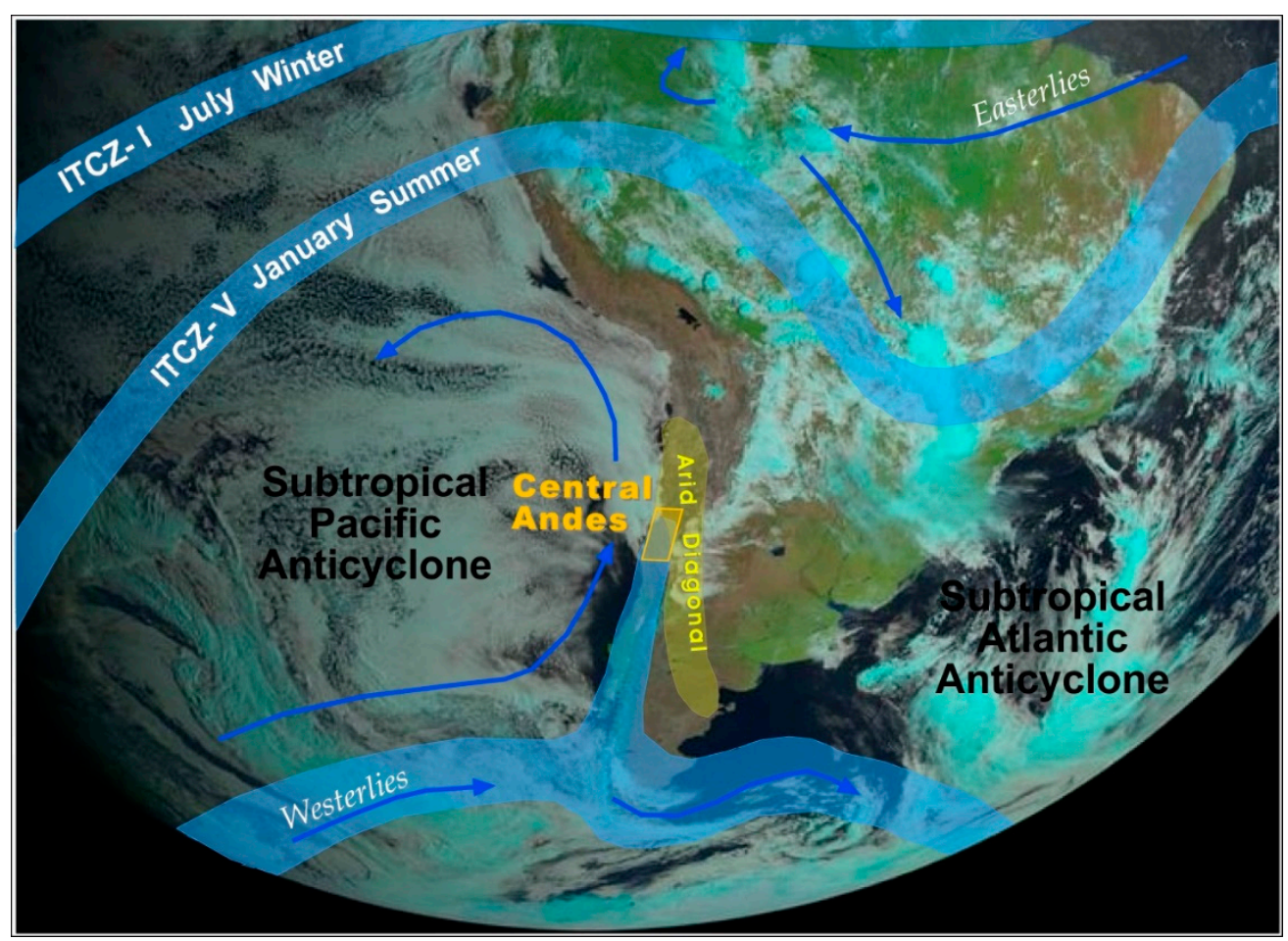

Figure 1. Climate framework settings of the study area showing the location of the Intertropical Convergence Zone (ITCZ) in summer and winter seasons forcing the humidity incomes (precipitations) from Atlantic or Pacific Anticyclones. Image corresponds to Goes-16 (Geostationary Operational Environmental Satellite) by the National Oceanic and Atmospheric Administration (NOAA) [29].

Topography and latitude strongly force temperature and precipitation distribution. Mountain ranges elevation decreases toward the south, favoring westerlies incoming the eastern side of the Andes (Argentina). The precipitation increases to the south due to the rising moisture flux from the Pacific Ocean and the weakening of the Southeast Pacific Subtropical Anticyclone. Between $30^{\circ}-32^{\circ} \mathrm{S}$ and $71^{\circ}-68^{\circ} \mathrm{W}$, the average precipitation reaches $100-400 \mathrm{~mm}$ per year [30], including solid precipitation in the highest mountain areas. The snow coverage shows seasonal and inter-annual variations. Maximum solid precipitation occurs during the winter season, reaching $58 \%$ of the annual average snow coverage. Snow coverage reaches $12 \%$ during dry inter-annual periods against the highest incidence of snowfall periods with an average cover of $32 \%$ [31]. Anomalous winter precipitation has been associated with the El Niño-Southern Oscillation (ENSO) phenomenon [32]. Above mean precipitations are recorded on the Andes range during the warm phase. Opposite conditions prevail during the cold phase [24]. Likewise, the positive phase of the Pacific Decadal Oscillation (PDO) and the negative phase of the Antarctic Oscillation (AAO) match with increased winter precipitations [27]. Even though the ENSO impact on summer precipitation is rather weak [33], the precipitation variability is associated with equatorial symmetric circulation anomalies linked to ENSO-like warmer conditions after 1976/77 [34].

At present, this region is suffering a large drought receiving 30\% less rainfall than normal over the past decade due to a negative phase of the Pacific Decadal Oscillation (PDO) [15]. In 2019, central Chile had an 80\% rainfall deficit [16] (Figure 2). Climate models project a decrease in snowfall [35] and an increase of temperature [36] in the mountain areas of Central Andes. Meanwhile, the Mega-drought [16] has strongly forced the fire regime in the region in the last decade [37]. 


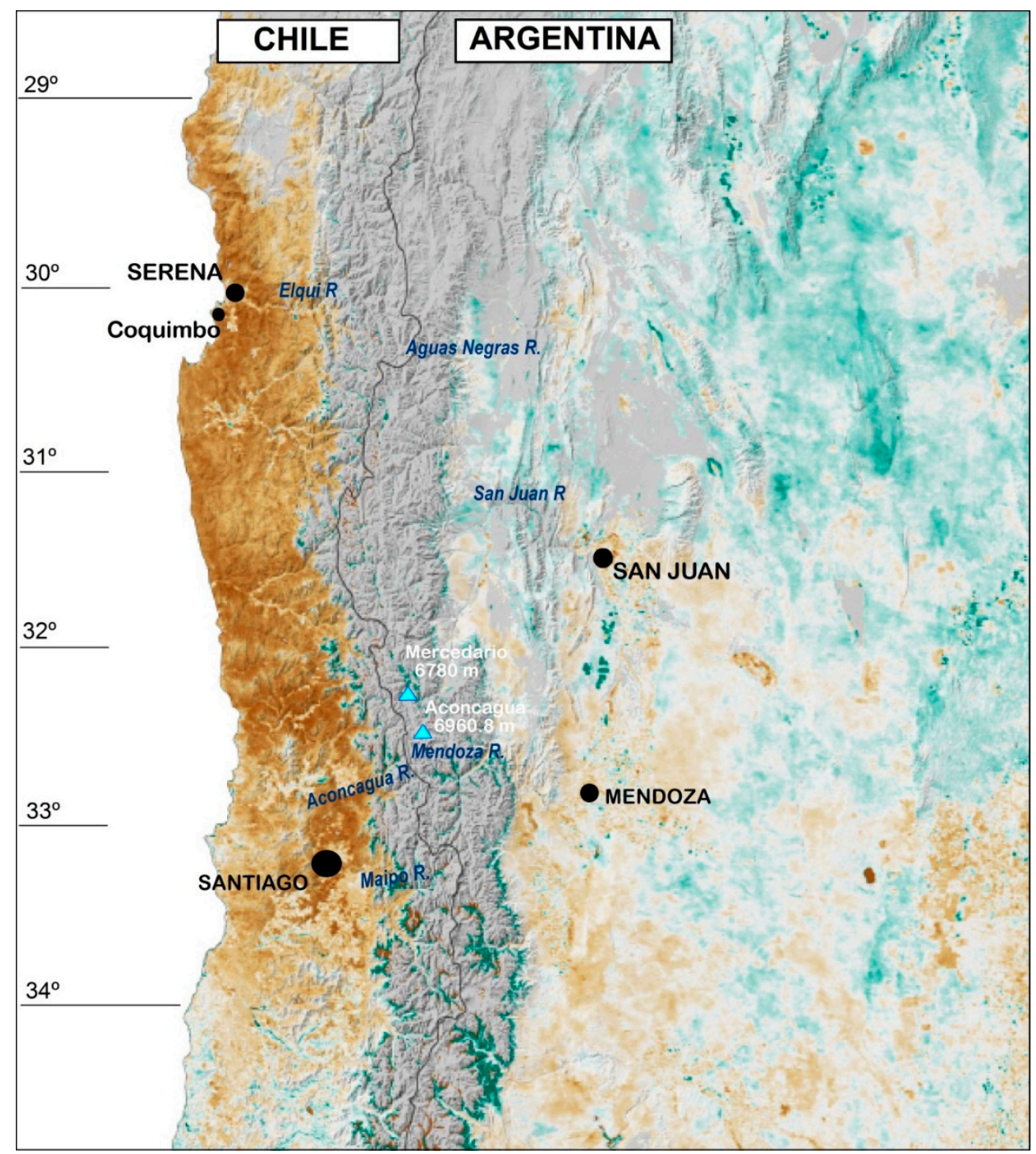

Figure 2. Image taken from NASA Earth Observatory contrasting vegetation health during the 20002010 period by Normalized Difference Vegetation Index (NDVI) [38]. Brown indicates vegetation that is less abundant and healthy than normal for this time. Gray highlights snowy and icy areas, or those with minimal vegetation. Green corresponds to abundant vegetation areas in valleys near glaciers and snow cover. The map was done by Lauren Dauphin, using MODIS data from NASA EOSDIS/LANCE and GIBS/Worldview and topographic data from the Shuttle Radar Topography Mission (SRTM).

\section{Geographical Context}

At these latitudes, the CA comprises different morpho-tectonic units from west to east, the Coastal Cordillera, the Main Cordillera, the Frontal Cordillera, and the Precordillera with very diverse lithologies. The Pampean flat slab segment, between $28^{\circ}$ and $32^{\circ} \mathrm{S}$, is related to an intense interplate and cortical seismicity, which has been related to landslides as well [39-41]. In this active tectonic segment of the CA, the highest peaks lay near $7 \mathrm{~km}$ (Aconcagua Mt $6960.8 \mathrm{~m}$ and Mercedario Mt $6780 \mathrm{~m}$ ). This abrupt topography environment with low temperatures favored the presence of glacial and periglacial landforms. Permafrost predominates above $3200 \mathrm{~m}$ asl, which is indicated by the presence of debris-rock glaciers [42].

The main valleys of the CA run at lower altitudes fed by other streams and creeks with intermittent flows that generate alluvial fans in their mouth. In this type of environment, mountain villages have been developed, which occasionally are severely affected 
by channeled debris flows or floods. Major routes connecting both sides of the Andes are located along the main valleys, which often cut alluvial fans and creeks subject to debris and hyperconcentrated flows. These routes constitute the main trade corridors of South America, linking the Pacific and Atlantic Oceans through terrestrial transport. Furthermore, the Andean piedmont, where all these fluvial systems discharge, coexist with the settlement of main capital cities: La Serena-Coquimbo ( $\left.30^{\circ} \mathrm{S}\right)$, Santiago $\left(33^{\circ} \mathrm{S}\right)$, San Juan $\left(31^{\circ} \mathrm{S}\right)$, and Mendoza $\left(32^{\circ} 30^{\prime} \mathrm{S}\right)$, which are historically affected by floods that are not considered in this review [43-46].

\section{Debris and Hyperconcentrated Flows}

The active tectonics and near-freezing temperatures of the high Andean mountains exacerbate sediment production feeding extensive valleys with steep slopes and long path gullies. This environmental context is associated with an arid-semiarid climate, where soil development and plant cover are low, which promotes erosion. The most efficient and common mechanism to remove these sediments is through aqueous fluidization. Andean catchments accumulate sediments commonly removed by sudden intense precipitations originating these debris/hyperconcentrated flows [39] mainly known as "aluviones" or "huaycos" in Latin America (Spanish or native terms).

Debris flows (DFs) are very rapid to extremely rapid (3 to $5 \mathrm{~m} / \mathrm{sec}$ ) gravity-driven flows composed of a mixture of debris and water $[47,48]$. They are recurrent phenomena within their path, since they usually follow pre-existing channels [49], and each event may include one single surge or several surges characterized by a coarse-grained head followed by a more liquid and fine-grained tail $[48,50]$. In CA, DFs are normally initiated on the basin headwaters of intermittent streamflows or dry creek by water saturation of hillslope material that moves downslope until the end of the alluvial system and deposit on fan landform. Whereas, hyperconcentrated flows (HFs) are defined as a two-phase turbulent flow composed of sediment-water mixtures that flow and behave as an intermediate flux between a normal streamflow or flood (mainly water with low fine sediments load) and a DF (higher proportion of coarse sediments than water) [50]. Even though HF was first defined according to a sediment concentration threshold of 20 to $60 \%$ [51] or $40-80 \%$ [52], more recent literature argue that these boundary values are arbitrary and not enough to define HF [50]. According to this author [50], HFs are unequivocal because of their high fluid viscosity due to suspended fine sediments that allow an intermittent dynamic suspension of coarse sediments (sand and fine gravel). Moreover, mean flow velocity and sediment loads transported by HF are greater than for water flow at analogous conditions of depth and slope.

When DFs lose coarse sediments by dilution and selective deposition, they may derive into HF. HF can also be generated when water flow entrains suspended sediments through valley erosion and entrainment. HFs are more related to streamflows saturated by sediments from upstream landslides or DFs or from natural or man-made dam collapse.

The failure of natural or artificial dams by overtopping, piping, or by mixing reservoir water with dam material may also generate outburst floods from naturally dammed lakes. In the CA, several glacial lake outburst floods (GLOFs) or landslide-dammed lakes outburst floods (LLOFs) have been reported [53-56]. A severe LLOF along the Santa Cruz River $\left(32^{\circ} \mathrm{S}\right)$ in 2005 damaged a dam under construction and caused problems on water supply in San Juan city [57-59]. These low-frequency phenomena provide massive volumes of water flowing at high-velocities that can evolve as DF or HF due to erosion and sediment entrainment processes $[50,60]$. Since lakes producing GLOFs and LLOFs are most of the time located in remote areas, the resulting outburst flood can be misjudged downstream as a DF or $\mathrm{HF}$, given that they were not originated by intense rainfall or the thaw of snow or frozen soil.

Finally, volcanic DFs, known as lahars, have not been reported in the study region, where Quaternary volcanic activity practically does not exist, starting south of $33^{\circ} \mathrm{S}$. Lahars are generated by the mobilization of tephra deposits laying on hillslopes due to intense 
rainfall, snow, or ice melting or geothermal heating. Nonetheless, the role in DFs occurrence from the mobilization of laying pyroclastic material ejected from large historical eruptions further south $\left(33^{\circ}-36^{\circ}\right.$ S- e.g., Quizapu volcano) has not been analyzed in the study area yet.

\subsection{Debris Flows, Hyperconcentrated Flows, and Debris Flood Records}

During the 19th century, landslides were rarely reported by foreign travelers crossing the Andes along the Mendoza Valley (32 S) [61-65]. Santiago Molina, a muleteer, was killed by a falling block at Cortaderas locality in 1790 according to the communication of Miers [61] during his voyage in 1819. Afterward, landslide studies began to gain importance after the construction of mountain roads construction during the late 19th century [66] and with the Transandino railway operation along the Aconcagua (Chile) and Mendoza (Argentina) valleys [67]. Fatalities caused by falls, extreme cold, and snow avalanches along these corridors are reported by Osculati in 1834 (In: [68]), and serious damages on the Transandino railway were reported in 1890 during its inauguration (Los Andes, 1890 in [69]). Facilities and villages growing along the Andean valleys escalated landslides and snow avalanches records in the Argentinian side. Verdaguer [70] mentioned damage caused by rain-triggered DFs in the Precordillera during the summer of 1824 along Mendoza Valley $\left(32^{\circ} \mathrm{S}\right)$.

On the other hand, historical floods and flows in the Elqui River $\left(30^{\circ} \mathrm{S}\right)$ have been recorded since 1827 [71,72] (Figure 3). At least seven flood events were recorded from 1833 to 1915 by historian José Varela [73] and $\approx 71 \%$ of total floods (373 floods) recorded in between 1981 and 1990 correspond to the Elqui valley [45]. Particularly, several damaging debris flows were reported in the Elqui Valley after a hard colder winter in 1880. Violent DFs in Leiva and Uchumí creeks destroyed the railway along the Elqui valley in 1988, isolating the Vicuña village. The Algarrobal DF was an extraordinary event that occurred on May 21, 1934, which was triggered after $120 \mathrm{~mm}$ of rainfall in $72 \mathrm{~h} \mathrm{[73].} \mathrm{A} \mathrm{bridge} \mathrm{from} \mathrm{Algarrobal}$ creek (Rivadavia village) was dragged all the way to Diaguitas village more than $10 \mathrm{~km}$ downstream, where it destroyed the Andallito bridge. The Vicuña bridge and the railway were also completely damaged, leaving these mountain communities isolated. During the same rainstorm, a debris flow channelized in the Uchumí creek and dammed the Elqui River, generating a $10 \mathrm{~m}$ high lagoon that was fortunately quickly emptied $2 \mathrm{~h}$ later [73]. The most violent events were reported in Rivadavia village, where DFs coming from the San Juan and Cementerio creeks generated serious loses downstream. The material also blocked the Elqui River in the Cerda bridge. The dammed lagoon reached $500 \mathrm{~m}$ long and $10 \mathrm{~m}$ high, collapsing drastically with catastrophic consequences downstream [73].

The Diaguitas DF $\left(30^{\circ} \mathrm{S}\right)$ struck the Vicuña village on 22 April 2004, during the night, after intense rain ( $90 \mathrm{~mm}$ in $12 \mathrm{~h}$ ). Several tons of muddy material with blocks of different size, trunks, and branches came down from the Puyalles creek. This catastrophic event affected 150 families, injured 60 people, destroyed some houses, eroded farmland, razed grapevines, and devastated the irrigation system. The village's school was covered by a muddy layer of $0.70 \mathrm{~m} \mathrm{[74].} \mathrm{Losses} \mathrm{were} \mathrm{estimated} \mathrm{between} \mathrm{six} \mathrm{and} \mathrm{eight} \mathrm{million}$ dollars [75].

The most catastrophic DF of central Chile occurred in November 1987 on the Colorado River catchment $\left(33^{\circ} \mathrm{S}\right)$. The Parraguirre rock slide-avalanche [76] generated a DF that destroyed the fields, roads, bridges, and damaged the under-construction Alfalfal hydroelectric power plant along the Colorado River. This event caused 41 fatalities $[1,2,77]$. The DF reached an estimated volume ranging from 2.5 to $15 \times 10^{6}$ cubic meters [2]. A summary of the main historic DF and HF events in central Chile is presented in Table 1. 


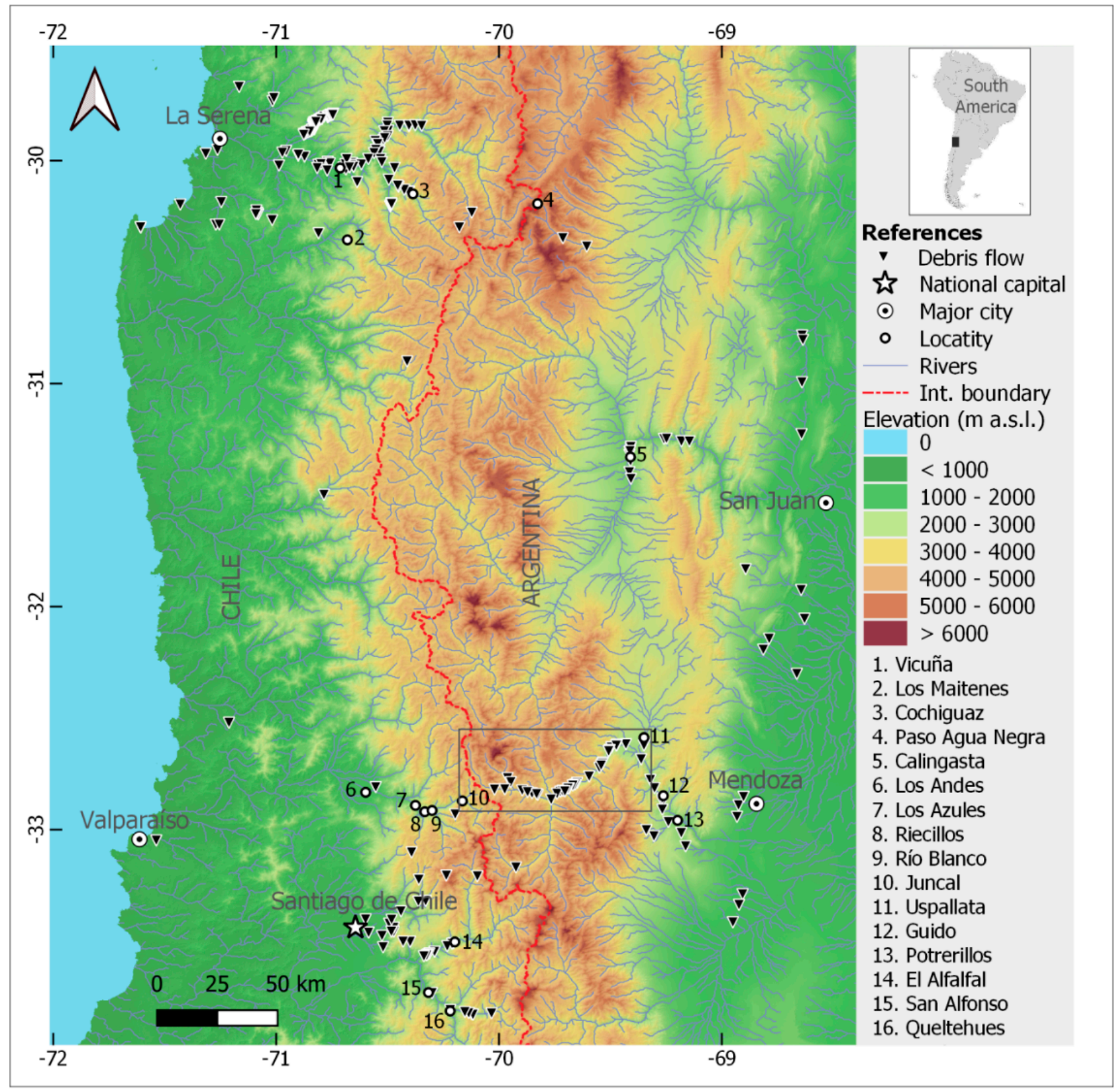

Figure 3. Historical debris flows recorded in the study area $\left(30^{\circ}-33^{\circ} \mathrm{S}\right)$ mainly in villages and along the mountain corridors. Rectangle corresponds to the Mendoza River Valley. 
Table 1. Historic records of debris flows in Chilean central Andes $\left(30^{\circ}-33^{\circ} \mathrm{S}\right)$.

\begin{tabular}{|c|c|c|c|c|c|c|c|c|}
\hline $\begin{array}{l}\text { Main River } \\
\text { Valley }\end{array}$ & River or Locality & $\begin{array}{l}\text { Coordinates } \\
\text { (DMS System) }\end{array}$ & Date & Classification & Trigger & $\begin{array}{l}\text { Damages to People } \\
\text { and Properties }\end{array}$ & Source & Notes \\
\hline & & & & Coquimbo Region & & & & \\
\hline & Rivadavia locality & $30^{\circ} 05^{\prime} \mathrm{S}, 70^{\circ} 06^{\prime} \mathrm{W}$ & 21 May 1934 & $\begin{array}{l}\text { Several DFs from } \\
\text { different creeks } \\
\text { (Santa Gracia, } \\
\text { Algarrobo, } \\
\text { Uchumi) between } \\
\text { Rivadavia and } \\
\text { Diaguitas villages. } \\
\text { San Juan and } \\
\text { Cementerio creeks }\end{array}$ & $\begin{array}{l}120 \mathrm{~mm}-72 \mathrm{~h} \\
\text { rainfall }\end{array}$ & $\begin{array}{c}\text { Several bridges } \\
\text { damaged along Elqui } \\
\text { River (Algarrobal, } \\
\text { Diaguitas Andallito } \\
\text { Vicuña). } \\
\text { LLOF induced by a } \\
\text { DF blockage of the } \\
\text { Elqui River }\end{array}$ & {$[72]$} & $\begin{array}{l}\text { DF from Uchumi } \\
\text { creek dammed the } \\
\text { Elqui River } \\
\text { generating a } 10 \mathrm{~m} \\
\text { high lagoon. }\end{array}$ \\
\hline & Vicuña locality & $30^{\circ} 01^{\prime} \mathrm{S}, 70^{\circ} 41^{\prime} \mathrm{W}$ & Spring, 1988 & $\mathrm{DF}$ & & Railway destroyed & {$[72]$} & $\begin{array}{l}\text { Leiva and Uchumi } \\
\text { creeks }\end{array}$ \\
\hline & $\begin{array}{l}\text { Los Maitenes } \\
\text { locality }\end{array}$ & $30^{\circ} 19^{\prime} \mathrm{S}, 70^{\circ} 48^{\prime} \mathrm{W}$ & 24 March 1992 & DF and mudflow & & & {$[1]$} & $\begin{array}{l}\text { DF and mudflows } \\
\text { at El Llano gully }\end{array}$ \\
\hline \multirow[t]{5}{*}{$\begin{array}{c}\text { Elqui } \\
\left(29^{\circ} 54^{\prime} \mathrm{S}\right)\end{array}$} & La Serena locality & $29^{\circ} 54^{\prime} \mathrm{S}$ & Winter, 1997 & DF and HF & $\begin{array}{l}\text { Heavy rainfall } \\
\text { associated with } \\
\text { the very strong } \\
\text { ENSO event }\end{array}$ & $\begin{array}{l}\text { Route disruption } \\
\text { between La Serena } \\
\text { and Vallenar }\end{array}$ & [45] & \\
\hline & Turbio River & $29^{\circ} 58^{\prime} \mathrm{S}, 70^{\circ} 54^{\prime} \mathrm{W}$ & 18 June 1997 & $\mathrm{DF}$ & & $\begin{array}{c}\text { Two fatalities, two } \\
\text { people injured and } \\
140 \text { refugees }\end{array}$ & [45] & $\begin{array}{c}\text { DF in El } \\
\text { Almendral, next to } \\
\text { La Vicuña locality }\end{array}$ \\
\hline & Vicuña locality & $30^{\circ} 01^{\prime} \mathrm{S}, 70^{\circ} 41^{\prime} \mathrm{W}$ & 22 April 2004 & $\mathrm{DF}$ & $\begin{array}{l}90 \mathrm{~mm}-12 \mathrm{~h} \\
\text { rainfall }\end{array}$ & $\begin{array}{c}150 \text { affected families } \\
\text { and } 60 \text { injured } \\
\text { persons. Houses, } \\
\text { farmlands and } \\
\text { grapevines destroyed. } \\
\text { Irrigation system and } \\
\text { school devastated. } \\
\text { Economic lost US } \$ 6-8 \\
\text { millions }\end{array}$ & [72] & $\begin{array}{l}\text { Diaguitas DF. } \\
\text { Puyalles creek }\end{array}$ \\
\hline & Cochiguaz River & $30^{\circ} 08^{\prime} \mathrm{S}, 70^{\circ} 23^{\prime} \mathrm{W}$ & 6 February 2006 & $\mathrm{DF}$ & Heavy rainfall & & & \\
\hline & $\begin{array}{c}\text { Difunta Correa } \\
\text { ravine }\end{array}$ & $30^{\circ} 10^{\prime} \mathrm{S}, 70^{\circ} 02^{\prime} \mathrm{W}$ & $\begin{array}{l}\text { From } 26 \text { to } 28 \\
\text { December } 2011\end{array}$ & DF cluster & $\begin{array}{l}\text { Snow and/or } \\
\text { interstitial ice } \\
\text { melting }\end{array}$ & Route interruption & {$[78]$} & \\
\hline
\end{tabular}


Table 1. Cont.

\begin{tabular}{|c|c|c|c|c|c|c|c|c|}
\hline $\begin{array}{l}\text { Main River } \\
\text { Valley }\end{array}$ & River or Locality & $\begin{array}{l}\text { Coordinates } \\
\text { (DMS System) }\end{array}$ & Date & Classification & Trigger & $\begin{array}{l}\text { Damages to People } \\
\text { and Properties }\end{array}$ & Source & Notes \\
\hline & $\begin{array}{c}\text { Huanta and } \\
\text { Varillar localities }\end{array}$ & $29^{\circ} 49^{\prime} \mathrm{S}, 70^{\circ} 24^{\prime} \mathrm{W}$ & $\begin{array}{l}24 \text { and } 25 \text { March } \\
2015\end{array}$ & DF & Heavy rainfall & $\begin{array}{l}\text { Route interruption } \\
\text { and partial blockage } \\
\text { of the Turbio River }\end{array}$ & [79] & $\begin{array}{c}\text { Culebra and Seca } \\
\text { ravines }\end{array}$ \\
\hline & $\begin{array}{l}\text { Difunta Correa } \\
\text { ravine }\end{array}$ & $30^{\circ} 10^{\prime} \mathrm{S}, 70^{\circ} 02^{\prime} \mathrm{W}$ & $\begin{array}{l}\text { From } 20 \text { to } 22 \\
\text { January } 2016\end{array}$ & DF cluster & $\begin{array}{l}\text { Snow and/or } \\
\text { interstitial ice } \\
\text { melting }\end{array}$ & Route interruption & [78] & \\
\hline & $\begin{array}{l}\text { Difunta Correa } \\
\text { ravine }\end{array}$ & $30^{\circ} 10^{\prime} \mathrm{S}, 70^{\circ} 02^{\prime} \mathrm{W}$ & $\begin{array}{l}\text { From } 12 \text { to } 16 \\
\text { January } 2017\end{array}$ & DF cluster & $\begin{array}{l}\text { Snow and/or } \\
\text { interstitial ice } \\
\text { melting }\end{array}$ & Route interruption & [78] & $\begin{array}{c}\text { Due to this event } \\
\text { the route location } \\
\text { was changed }\end{array}$ \\
\hline $\begin{array}{l}\text { Limarí } \\
\left(30^{\circ} 43^{\prime} \mathrm{S}\right)\end{array}$ & $\begin{array}{l}\text { Hurtado River } \\
\quad\left(30^{\circ} 21^{\prime} \mathrm{S}\right)\end{array}$ & $30^{\circ} 21^{\prime} \mathrm{S}, 70^{\circ} 40^{\prime} \mathrm{W}$ & June and July 1987 & $\mathrm{DF}$ & $\begin{array}{l}\text { A three weeks } \\
\text { frontal system } \\
\text { affected the region }\end{array}$ & $\begin{array}{c}\text { Several houses were } \\
\text { damaged in Los } \\
\text { Maitenes (El Llano } \\
\text { gully) } \\
\text { Three fatalities. } \\
\text { Drinking water } \\
\text { supply interrupted } \\
\text { due to high sediments } \\
\text { loads, houses } \\
\text { damaged, three } \\
\text { bridges destroyed }\end{array}$ & [45] & \\
\hline \multicolumn{9}{|c|}{ Metropolitan Region } \\
\hline $\begin{array}{l}\text { Mapocho River } \\
\quad\left(33^{\circ} 19^{\prime} \mathrm{S}\right)\end{array}$ & $\begin{array}{l}\text { San Francisco } \\
\text { River }\end{array}$ & $33^{\circ} 19^{\prime} \mathrm{S}, 70^{\circ} 21^{\prime} \mathrm{W}$ & $\begin{array}{c}21 \text { and } 22 \\
\text { February } 1980\end{array}$ & DF & & $\begin{array}{l}\text { Three fatalities, four } \\
\text { missing people, and } \\
580 \text { refugees } \\
\text { Estimated damages of } \\
\text { US } \$ 500,000\end{array}$ & [45] & \\
\hline \multirow{4}{*}{$\begin{array}{l}\text { Maipo River } \\
\left(33^{\circ} 50^{\prime} \mathrm{S}\right)\end{array}$} & Santiago & $33^{\circ} 27^{\prime} \mathrm{S}, 70^{\circ} 29^{\prime} \mathrm{W}$ & 1908 & DF and mudflows & & & {$[1]$} & Macul creek \\
\hline & Santiago & $33^{\circ} 24^{\prime} \mathrm{S}, 70^{\circ} 29^{\prime} \mathrm{W}$ & 1936 & DF & & & [1] & Macul creek \\
\hline & Santiago & $33^{\circ} 25^{\prime} \mathrm{S}, 70^{\circ} 30^{\prime} \mathrm{W}$ & 1957 & Mudflows & & & {$[1]$} & Macul creek \\
\hline & $\begin{array}{l}\text { Mapocho, Maipo, } \\
\text { Colorado and Yeso } \\
\text { rivers }\end{array}$ & & March 1980 & DF & & $\begin{array}{l}\text { Route interruptions } \\
\text { and damages to } \\
\text { infrastructures }\end{array}$ & [45] & Several DF \\
\hline
\end{tabular}


Table 1. Cont.

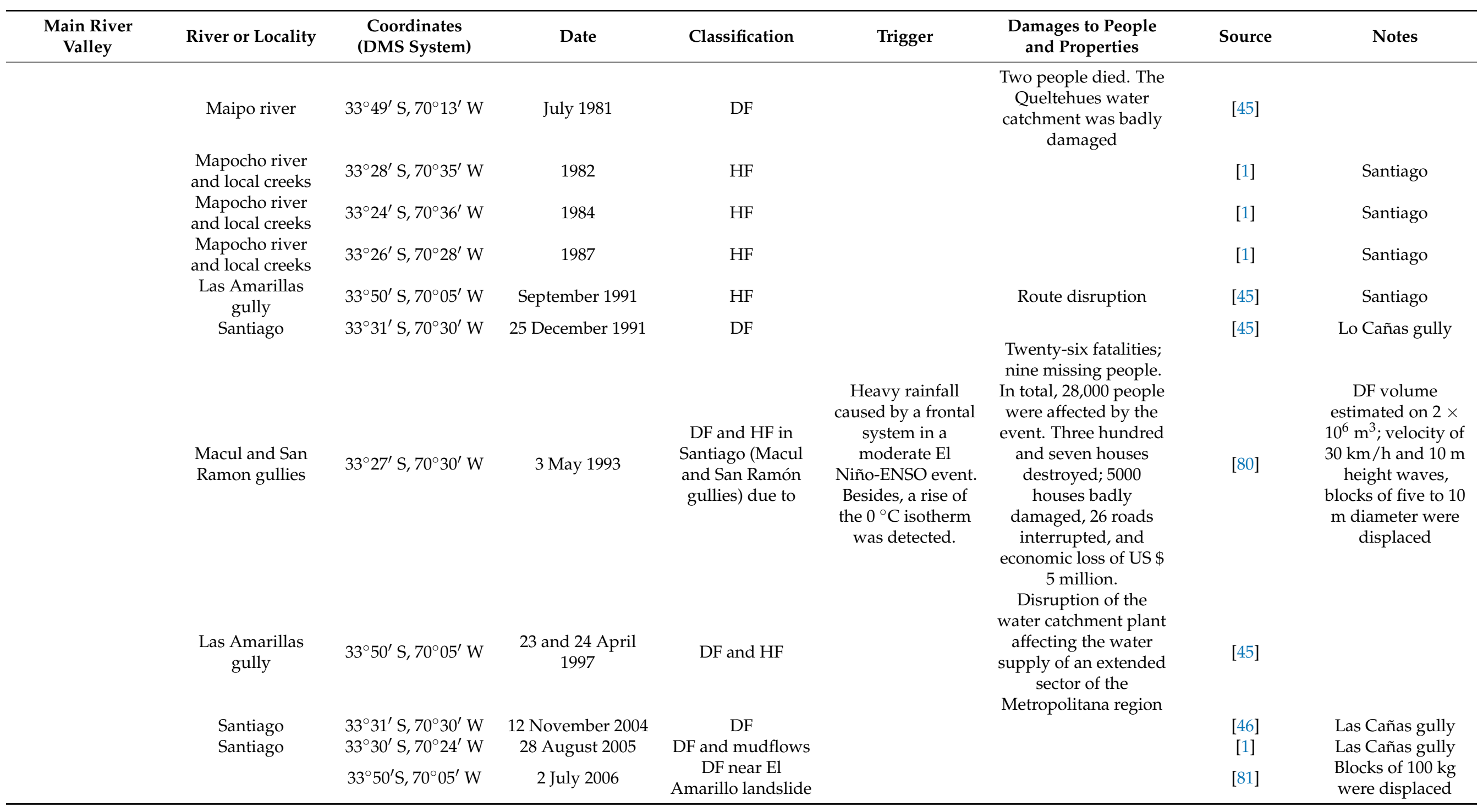


Table 1. Cont.

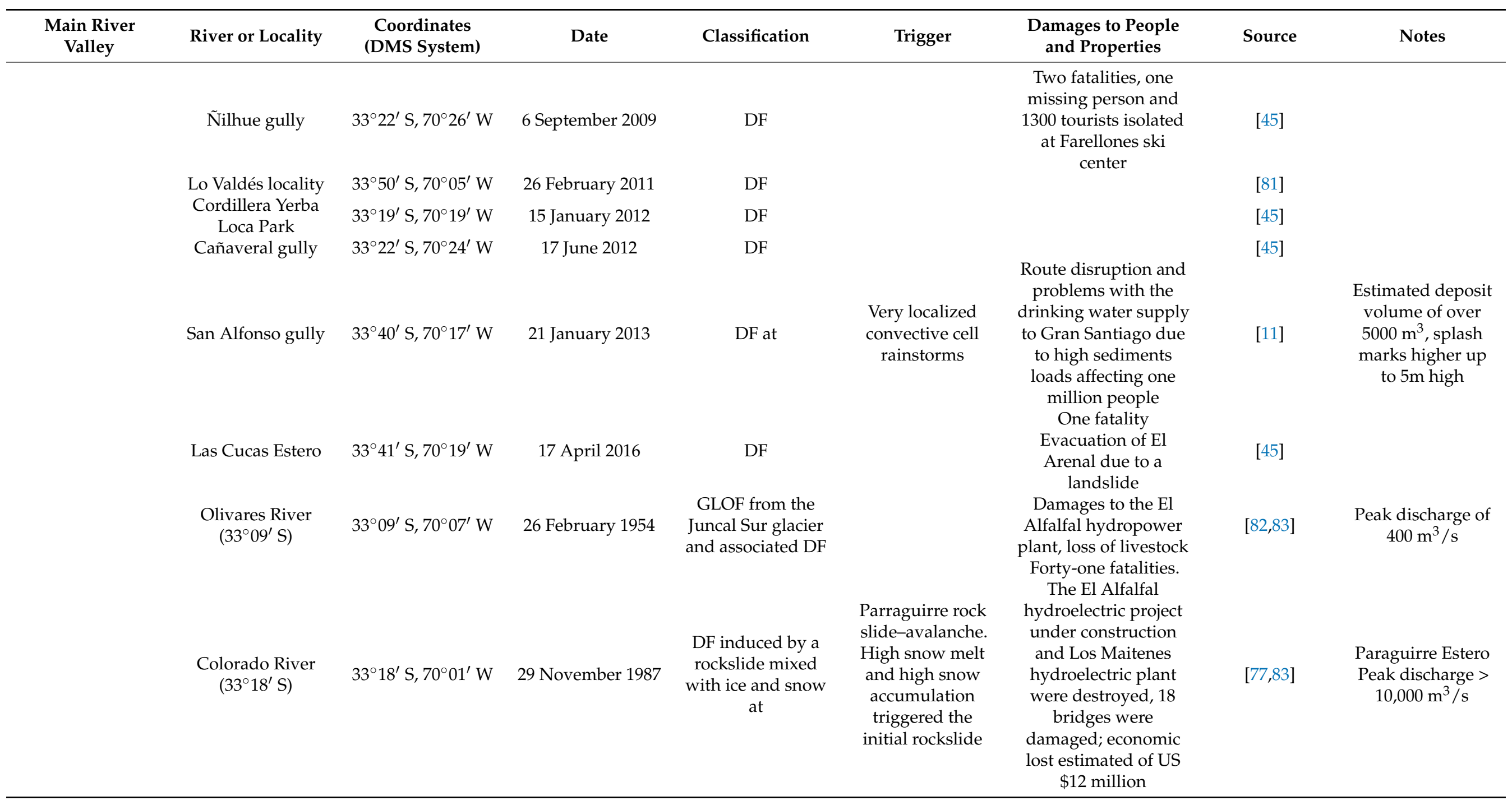


Table 1. Cont.

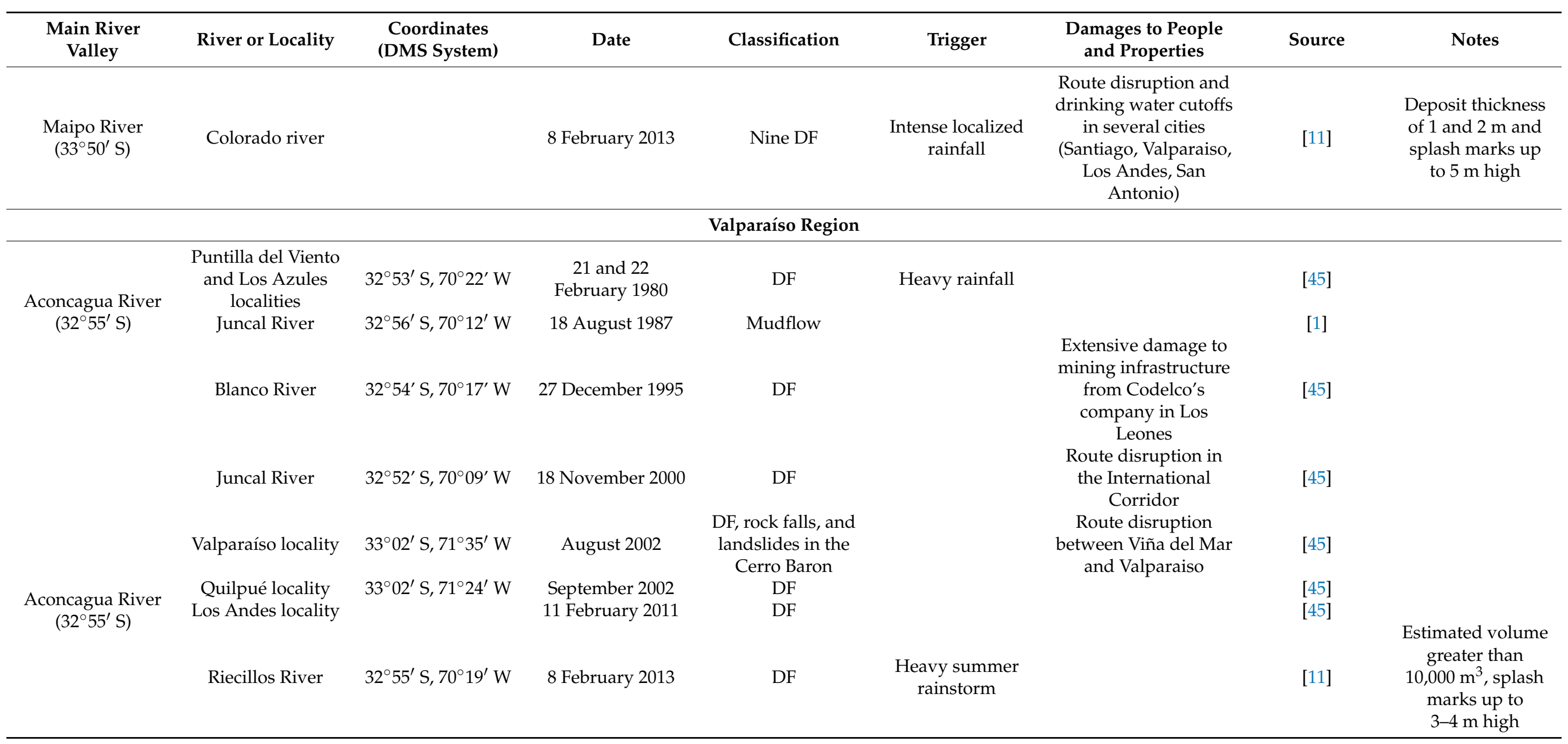


On the Argentinean side of the Andes, an extensive record of more than 300 historical DFs exists for the Mendoza Valley $\left(32^{\circ} 30^{\prime} \mathrm{S}\right)[7,17,19]$. The most dangerous reported DFs were channelized in the Seca and Camino creeks in 1976, 1980, 1999, and 2000. One of these events dragged a car in 1968. Another DF from Avispas Creek dragged out a lorry that fell into the Mendoza River with one fatality. Violent DFs have been reported as well in the Polcura (known as 60 creek) and Guido locality in 1999, 2001, and 2005, swamping the international road $[17,84]$. Based on these records, a recurrence interval of 4 years was estimated for the Frontal Cordillera, while this interval is higher (15 years) for the Precordillera [7].

Along the Blanco Valley ( $\left.33^{\circ} \mathrm{S}\right)$, many damaging DFs were recorded in the main creeks as Salto, Angostura, Mulas, and Colorada, impacting adversely the local population [10]. Damaging torrents were reported in January 1946, destroying a bridge in Chacritas, and in January 1947, affecting a school at Potrerillos village. On December 1954 and 1955, an intense rainstorm generated several debris falls along the Colorada creek, disallowing the access to the Vallecitos ski tourist complex. A DF cut again the access on 7th February 1967. Finally, the 7th February 2013 another DF channeled in Las Mulas creek destroyed a small bridge and isolated people in the Valle del Sol locality. This event severely affected the drinking water supply of these communities for at least four days [85].

After an intense rainfall affecting the central-west part of Argentina on February 8th, 2013, a DF affected the Agua Negra international road $\left(30^{\circ} 20^{\prime} \mathrm{S}\right)$. This road connects the Agua Negra valley, San Juan (Argentina) with Elqui valley (Road CH40), and Coquimbo-La Serena (Chile). Unfortunately, this event led to the death of a 10-year-old boy when the vehicle in which he was traveling lost control trying to pass the muddy moving mass material. The material volume was estimated at $50,000 \mathrm{~m}^{3}$ with an average speed of $35 \mathrm{~km} / \mathrm{h}$. As a result, the international road was closed for several days and isolated 11 families at the Chilean customs [86].

Impacts of DF and HF generated by intensive summer rainstorms have been also documented for the lowlands. Polanski [87] studied these processes proposing a classification for DF and floods based on their deposit characteristics in this arid region.

\subsection{Debris Flows Characterization}

Both DF and HF constitute hazardous processes due to their great velocity, long runout distance (several $\mathrm{km}$ ), and high impact loads capable of moving large boulders and trees, implying significant destructive power [88]. The estimated volume of DF in the CA fluctuates from $250 \mathrm{~m}^{3}$ [11] to $15 \times 10^{6} \mathrm{~m}^{3}$ [76]; these values are possibly underestimated, as the real water volume is rarely known. Figure 4 shows that greater recorded volumes correspond to GLOF and LLOF. The transported material can involve boulders up to $4 \mathrm{~m}$ in diameter. The DF recorded in Juncal valley ( $32^{\circ}$ S, Valparaíso region) on 18th August 1987 removed a $450 \mathrm{t}$ stone. Boulder and block material tends to be thicker in Chile hillslopes than in Argentina side with more gentle slope basins [11]. Nonetheless, many mud flows have been described in Elqui valley $\left(30^{\circ} \mathrm{S}\right)$ (Table 1). Less common are wood-laden flow (WLF) in this semiarid region, even though a WLF event was described in February 2017 in the Pocuro stream (Central Chile, 33 S) [89].

Different flood or flow pulses are often generated because the sediments form dams that contain the flow for a variable time, and when these give in, a new flood pulse is generated [76,80]. Flood heights of 0.7 to $35 \mathrm{~m}$ depositing 1 to $5 \mathrm{~m}$ of sediments $[7,10,11]$ have been reported.

The larger sizes of Andean catchments influence a large debris supply, while steep slopes exacerbate the flows velocity. The $\mathrm{DF} / \mathrm{HF}$ affecting this region are relatively highspeed events with velocities exceeding $30 \mathrm{~km} / \mathrm{h}[76,90]$. In the Mendoza Valley $\left(32^{\circ} 50^{\prime} \mathrm{S}\right)$, some DFs reach $126-180 \mathrm{~km} / \mathrm{h}$ in very steep ravines [41]. Historical DFs caused by rainstorm during summer seasons in Anchoris ( $33^{\circ} \mathrm{S}$ ) reach $1-2 \mathrm{~m} \cdot \mathrm{s}^{-1}$ in velocity, remobilizing a great amount of fine material [87]. The velocity of $4.7 \mathrm{~m} \cdot \mathrm{s}^{-1}$ for the first phase of the event was estimated from videos recording in Pocuro [89]. Curiously, higher speeds were 
indirectly established for the Amarilla creek and Paraguirre DF, whereas lower velocities were estimated for historical GLOF (Figure 4).
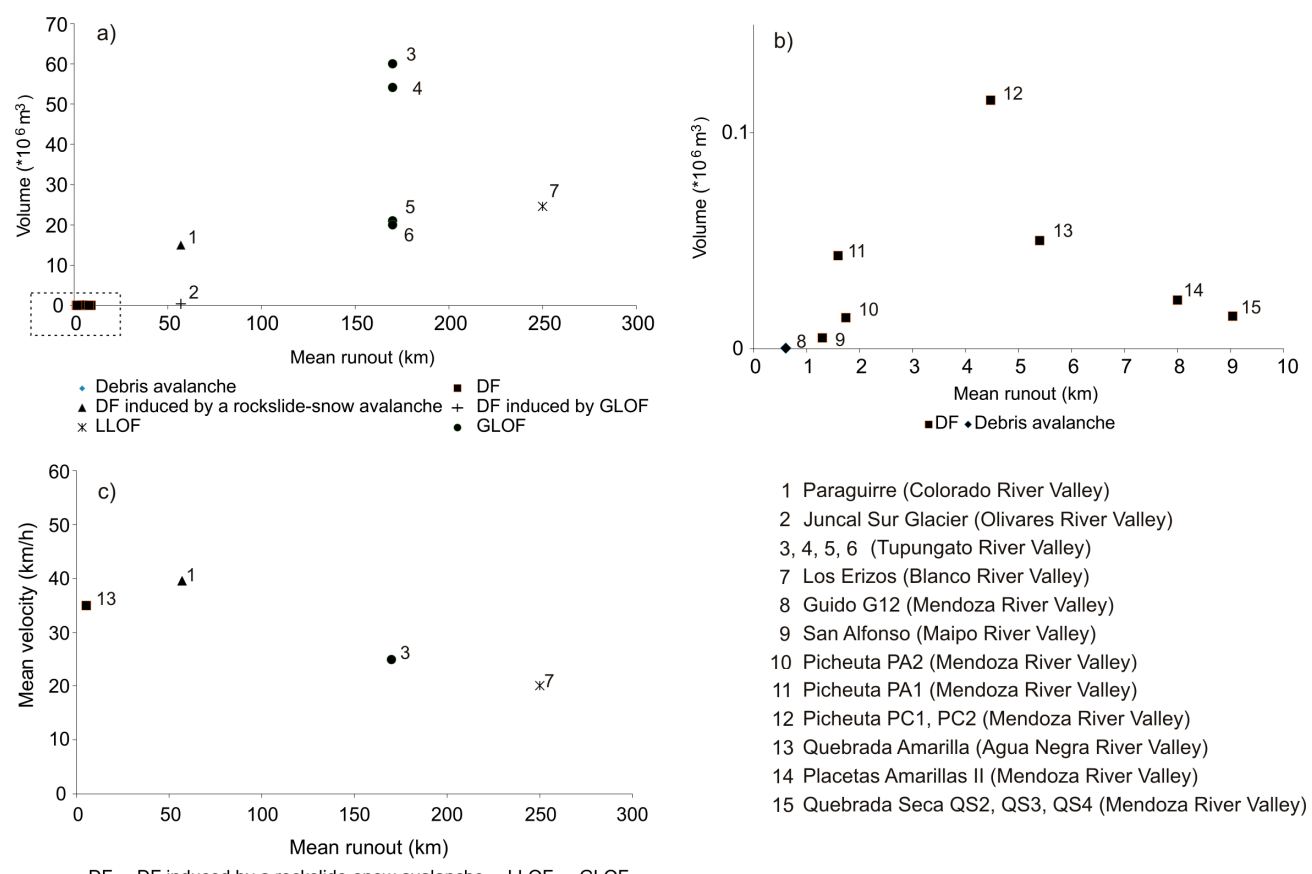

1 Paraguirre (Colorado River Valley)

2 Juncal Sur Glacier (Olivares River Valley)

3, 4, 5, 6 (Tupungato River Valley)

7 Los Erizos (Blanco River Valley)

8 Guido G12 (Mendoza River Valley)

9 San Alfonso (Maipo River Valley)

10 Picheuta PA2 (Mendoza River Valley)

11 Picheuta PA1 (Mendoza River Valley)

12 Picheuta PC1, PC2 (Mendoza River Valley)

13 Quebrada Amarilla (Agua Negra River Valley)

14 Placetas Amarillas II (Mendoza River Valley)

15 Quebrada Seca QS2, QS3, QS4 (Mendoza River Valley)

- DF $\triangle \mathrm{DF}$ induced by a rockslide-snow avalanche $*$ LLOF • GLOF

Figure 4. Parameters of recorded historical events when these parameters were estimated (a) relation between volume and mean runout; (b) zoom of events in the rectangle in a. (c) Relation between mean velocity and mean runout.

Channeled alluvial DFs mainly affect smaller catchments traveling short to moderate distances (up to $\approx 15 \mathrm{~km}$ ), but when they end into a main river streamflow, they may travel larger distances in order of $100 \mathrm{~km}$ or more. The travel distance of Andean DF/HF is very variable, which was probably linked to the catchment areas, slopes, and nature of mobilized material (Figure 4). GLOF and LLOF events have longer runouts (up to $\approx 250 \mathrm{~km}$ ). Still, outburst wave dissipation is strongly forced by the dammed lake volume. The Plomo GLOF event on 1934 reached $170 \mathrm{~km}$, developing a frontal wave of variable height (7 to $12 \mathrm{~m}$ ) according to the narrowing/widening of the valley. This event destroyed several kilometers of road and railways, seven bridges, a hydroelectrical power plant, and a hotel, affecting $750 \mathrm{~km}^{2}$ of cultivated land and killed 18 people [53]. Particularly, the HF generated by the Los Erizos LLOF event recorded the longer runout with a travel distance of $250 \mathrm{~km}$ (Figure 4).

Flow lubrication by ice input can propel excessive travel distances as well. This was

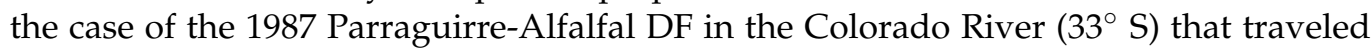
$50 \mathrm{~km}$ downstream arriving close to Santiago, the capital city of Chile [11]. Out of the study area, the Santa Lucia DF $\left(43^{\circ} 22^{\prime} \mathrm{S}, 72^{\circ} 22^{\prime} \mathrm{W}\right)$ on 16th December 2017 was generated by a $122 \mathrm{~mm}$ rainfall that triggered a rock slide that in turn caused partial melting of a receding glacier. The ice-debris mass traveled $10 \mathrm{~km}$ with an average speed of $72 \mathrm{~km} / \mathrm{h}$, mobilizing $7.2 \times 10^{6} \mathrm{~m}^{3}$. Two million cubic meters of sediments were deposited on the alluvial cone where the Santa Lucía village is settled, affecting 536 ha and resulting in 21 fatalities with a missing person [74].

\subsection{Spatial Distribution}

The reconstruction of debris flows occurrence, similar to another natural process in mountain areas, is strongly constrained by historical sources. The availability of chronological documents is rare in remote regions, and event reports are concentrated exclusively on the inhabited sectors along the Andean valleys (Figure 3). For this reason, inventories 
from remote sensors are becoming more significant in the CA and have partly overcome this limitation. From these inventories, the occurrence of DFs in high Andean altitudes dominated by a glacier environment has been ruled out [39,91,92] (Figure 5). However, those slopes located in lower positions related to periglacial domains where permafrost conditions could be affected by degradation take a key role [93-95].

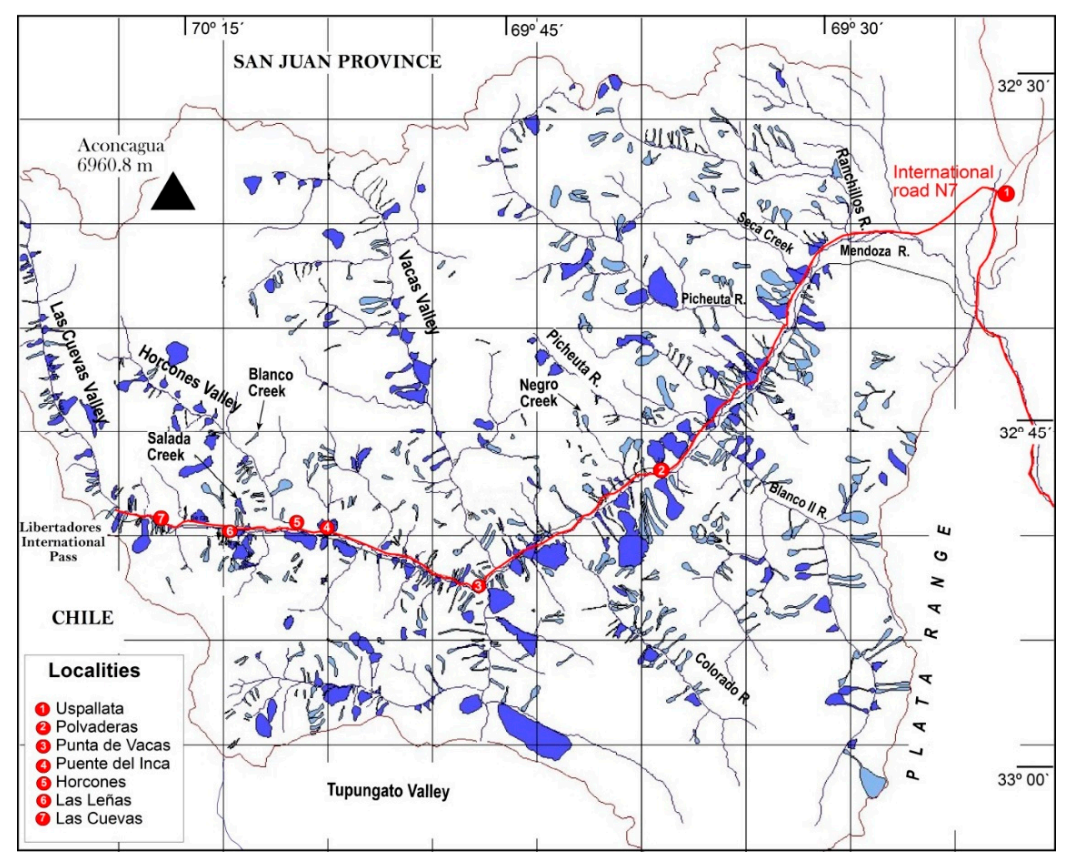

Figure 5. Inventory of debris flows (DFs) identified by remote sensing along the Mendoza Valley $\left(32^{\circ} 30^{\prime} \mathrm{S}\right)$ (after [96]). Light blue polygons represent an isolated DF and dark blue ones correspond to debris flows area where small DFs has been gathered. A limited spatial distribution of DFs is clearly observed in the highest mountain zones due to glacial domain. Along the main valley, several DF geoforms match with historical records (see Figure 3).

These findings match as well with reported DFs where $75 \%$ of these events occurred in the Frontal Cordillera with altitudes between 1880 and $2900 \mathrm{~m}$ asl along the Mendoza Valley $\left(32^{\circ}\right.$ S). Only $16 \%$ of the complex events happened in the higher Main Cordillera (heights between 3000 and almost 7000). The spatial distribution of historical DFs is constrained as well by the precipitations conditions. Snowfall over the higher catchments promotes snow avalanches during winter season, while DFs occur in the springtime associated with snow or ice thawing $[18,19,39]$ and rain induced-DFs occur in lower elevations areas of catchments during the summer season [17-19].

\section{Main Causes of Debris Flows in the Central Andes Region}

\subsection{Precipitation}

In this arid-semiarid region, DF/HF occurrence has been mostly associated with intense summer rainfall $[11,17,79,86,97,98]$. Most of them are convective storms associated with multiple synoptic conditions, such as the negative anomaly of the zonal component of the wind in the middle layers or, in certain cases, the presence of a cut-off low promotes the formation of convective storms on the eastern slopes of the Andes mountain range [99]. Meanwhile, in the western side of the Andes, DFs tend to occur not only linked to summer rainstorms but also to intense and persistent precipitation during winter.

Total day precipitation threshold values are relatively low compared to humid-climate environments. In the wetter Chilean side, daily precipitation of more than $60 \mathrm{~mm} / 24 \mathrm{~h}$ may trigger DFs in the CA ( $\left.33^{\circ} \mathrm{S}\right)$ [100]. However, DFs have been generated with $12 \mathrm{~mm} / \mathrm{h}$ in the Macul Creek (Santiago, $33^{\circ}$ S) $[80,101]$. In the driest eastern Argentinean side, a range between 6.5 and $12.9 \mathrm{~mm} / 24 \mathrm{~h}$ was determined for the historical DFs in the Mendoza 
Valley $\left(32^{\circ} 30^{\prime} \mathrm{S}\right)$ [17]. A very low threshold precipitation of $5.5 \mathrm{~mm} / 24 \mathrm{~h}$ was estimated for the 8F event in 2013 that occurred in the Amarilla creek (30 S, San Juan) [86] (Figure 6a). This threshold value was estimated using satellite rainfall data $(\mathrm{CMORPH})$, as weather stations in the surrounding area are lacking. Nonetheless, the influence of antecedent precipitation is not dismissed, as accumulated precipitation during previous days was of $13.2 \mathrm{~mm}$ in this case. The role of precipitation during the previous days was denoted as well for the events studied in the Mendoza River valley (32 $\mathrm{S}$ ), as $60 \%$ of the cases recorded precipitation until 3 or 5 previous days $[7,17]$. In Chile, the accumulated rainfall influence during 20-25 days before the event was found significant in the Andes mountain front at the latitude of Santiago ( $33^{\circ}$ S) [93]. Hence, not only the daily rainfall, but the accumulated rainfall and the altitude of the zero isotherm are crucial when analyzing the causes of DF in this region [46].

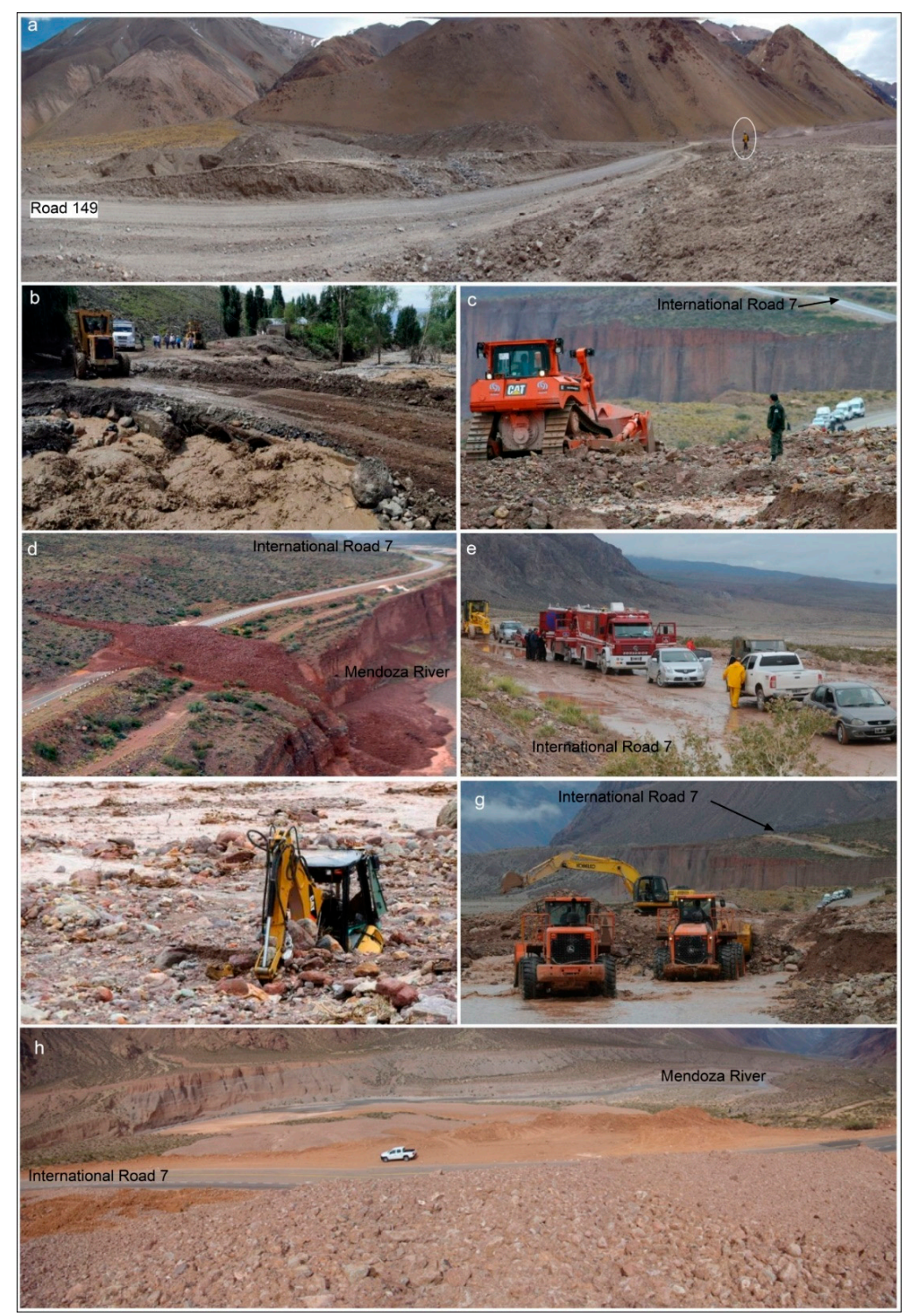

Figure 6. Events triggered by rainstorms during summer (a) event occurred on 8th February 2013 in the Agua Negra valley [71], in circle, a person as scale; (b) the bridge destroyed by the DF channeled in Las Mulas creek (Salto River, 33 ${ }^{\circ}$ S) on 7th February 2013 isolating the Valle del Sol locality [70]; (c,d) DFs in Picheuta area affecting the international road on 7th Feb 2013 [11]; (e-g) events recorded in Seca creek on 23th January, one roofed a bulldozer during the night [11]; and (h) event occurred in Picheuta region on 7th February 2015 with an estimated volume $\sim 115.000 \mathrm{~m}^{3}$ [11]. 
In the middle portion of the Elqui Valley $\left(30^{\circ} \mathrm{S}\right)$, where the probability of permafrost is limited to the highest summits, $1 \mathrm{~h}$ of precipitation is enough to trigger DFs and HFs [79]. The accumulated precipitation necessary for the triggering of DFs varies between 4.5 and $10 \mathrm{~mm}$ depending on zero-isotherm elevation, since for this area, the precipitation occurs fundamentally in winter (see Section 2). The triggering of HFs requires about two millimeters less for equal variations of the zero-isotherm elevation, but also for these events, their occurrence was not recorded for values less than $4.5 \mathrm{~mm} / 24 \mathrm{~h}$. Considering that HFs are generally lower energy phenomena (lower peak discharge, speed and size of suspended sediment than DF), it is logical that their liquid precipitation thresholds tend to be lower as well $[50,101]$. Unlike the southern CA, here, it was calculated that soil moisture preceding the rainfall burst does not condition the potential subsequent DFs occurrence, which could be due to different failure mechanisms and/or the more arid conditions of this sector that generate greater evapotranspiration [79].

The perspective of future temperature in the CA reveals a general rise [14]. A still series of summer precipitation of the Mendoza river valley shows a negative trend in the 1905-2018 period; this tendency varies. In fact, temperature trends will depend on the analyzed time period. Since 1965, precipitation has increased, matching with a sustained rise of DFs occurrence (Figure 7a). Although a greater number of DF have been recorded in the last decades, there is still more information to be collected to attribute a relationship between such events with climate change.

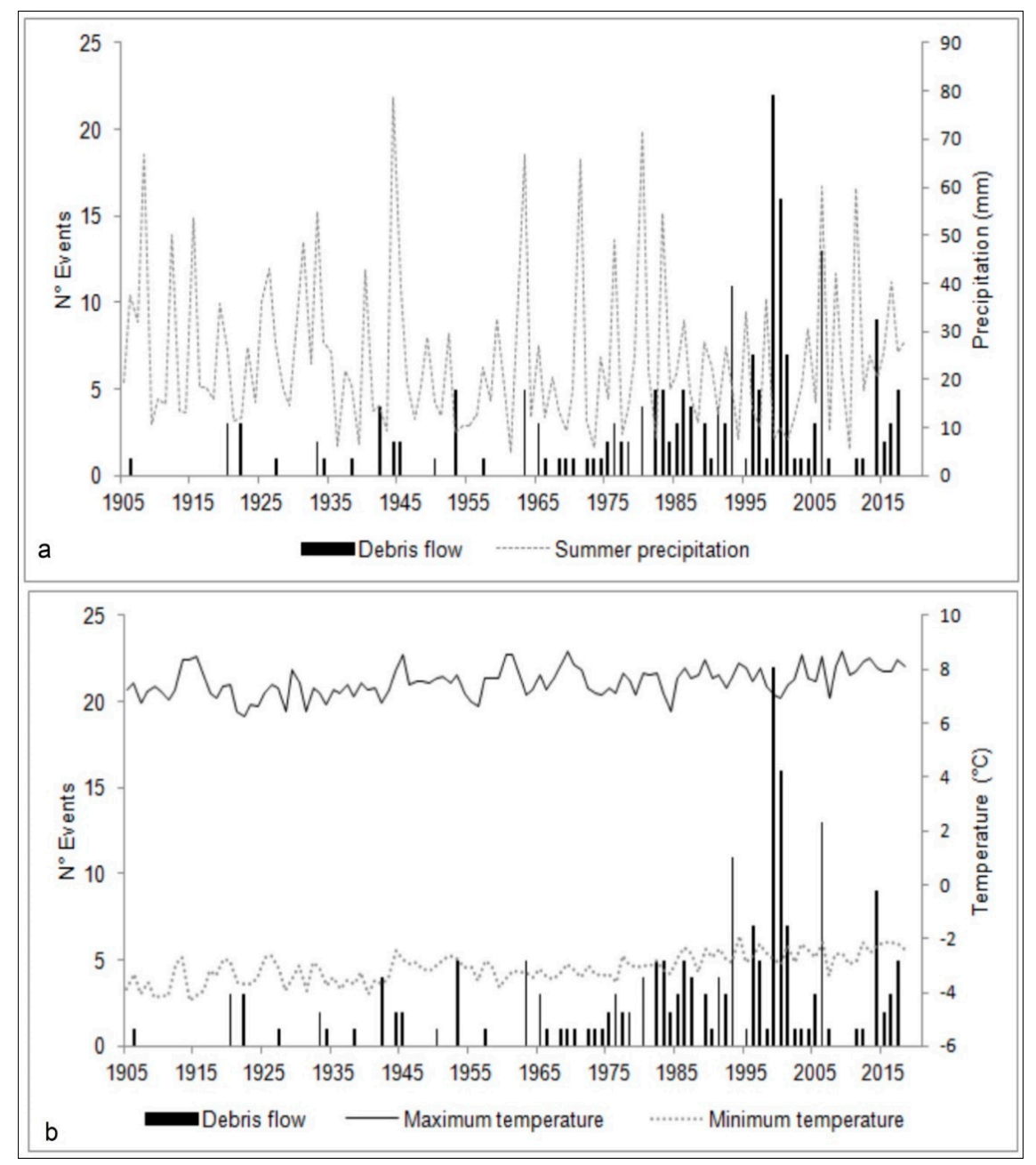

Figure 7. (a). Series of summer precipitation and documented DFs in the Mendoza river valley, and (b). Series of minimum and maximum annual temperatures and documented DFs in the Mendoza river valley. Records were obtained from database Climate Research Unit (CRU) TS4.03 [102]. 


\subsection{Temperatures and Zero-Isotherm}

Temperature is a key parameter for DFs generation in the mountain environment, as it influences the cryosphere melting [18,76,78]. Analysis of temperature series (1905-2018) of the Mendoza river valley shows a rising trend. This increase in temperatures could be correlated with more activity of DFs in this valley (Figure 7b).

Even though DFs from the melt of seasonal snow and ice within the active layer has lower frequency with respect to other triggering causal factors, DFs related to this melting processes have been recorded in some places (e.g., $[12,18,103])$. The Aconcagua Park ( $31^{\circ} \mathrm{S}$, Argentina) visited annually by more than 120,000 international tourists has been affected by violent DFs at the beginning of the warm season $[12,92,104]$. A DF coming from Durazno creek was reported in 1985, and another event was recorded in the Vacas valley in 2008 [105]. Moreover, two climbers reported an ice-core moraine expelling saturated fine material in the Vieja Alta Creek near the Plaza Guanacos camp in February 2004. This event partially blocked the Vacas River (Figure 8c) [105]. An amateur video recorded the DF on January 2016 in the Blanco alluvial fan after several days of successive increases in air temperature (video: https:/ / www.youtube.com/watch? $v=j N V w s p u n N n 0)$. This DF was generated from a creek with heavy snow accumulation coming from the Almacenes Sur Mount $(5410 \mathrm{~m})$. At least 3 pulses were recorded in this event (Figure 8a,b).

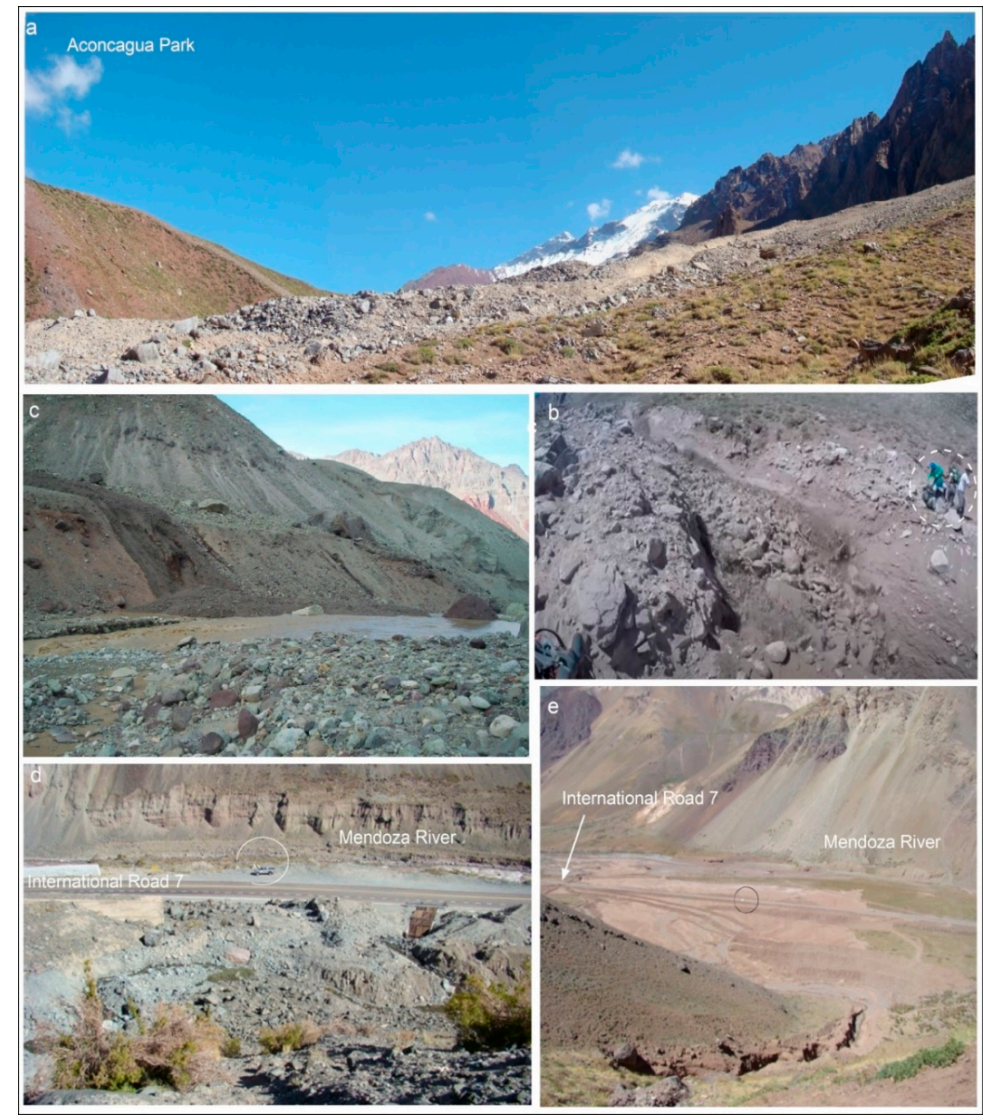

Figure 8. Events triggered by snow or glacial ice melting in Mendoza Valley ( $\left.32^{\circ} 50^{\prime} \mathrm{S}\right)$ (a) Ridges of historical DFs channeled in the alluvial fan of the Blanco creek (Aconcagua Park) [94]; (b) the DF occurred in January 2016 when tourists were crossing the Blanco creek [93]; (c) DF generated from an ice-core moraine in the Vieja Alta Creek near the Plaza Guanacos camp in February 2004 [104]; (d) DFs generated from a debris-rock glacier melting in the Negro creek on 28-29 December 2015 with an estimated volume of $30,018 \mathrm{~m}^{3}$ [12], the circle pointed out with a car; and (e) DFs caused by the melting of a debris-rock glacier in La Salada creek (Mendoza Valley $32^{\circ} 50^{\prime} \mathrm{S}$ ) with an estimated volume of $238,891 \mathrm{~m}^{3}$ [12], circle corresponds to a car. 
In December 2015, the successive climbing of the zero-isotherm produced the melting of a debris-rock glacier located in La Salada creek (Mendoza Valley $32^{\circ} \mathrm{S}$ ) generating four successive events that blocked the international road (Figure 8e). Due to this associated substrate warming, also, a debris-rock glacier located at the headwater of the Negro creek melted, triggering another three DFs during the same period [12] (Figure 8d). Those DFs generated by the melting of glacier tongues have generally performed successive events during several days, unlike in DFs triggered by rainfall, which have a sudden discharge in a single event, even though several pulses may occur.

Although direct measurement on soil temperatures is critical, the temperature is established by correlation with air temperatures or by insolation exposition [106]. The study of the thermo-radiative conditions previous, synchronous, and subsequent to debris flows from the melt of seasonal snow and ice within the active layer is complex in this region due to the scarce meteorological monitoring stations in the headwaters of the hazardous watersheds. In the upper basin of the Elqui Valley $\left(30^{\circ} \mathrm{S}\right)$, these events could be investigated in greater detail due to the good meteorological network of the area, with stations at hourly resolution and located at high elevations [78,79]. The debris flows have several thermo-radiative patterns such as (a) greater correlation with the daily accumulation of heat available for melting than with the daily maximum in this heating, (b) occurrence in clusters of 3-5 days during the early summer, (c) initiation of clusters at the warmest day until that moment of the summer trimester, and (d) an accelerated increase in temperature over the days previous to the beginning of the clusters. However, the amount of water generated by summer snowmelt or melting of the active permafrost layer is still uncertain in the CA [78].

\subsection{Climate Phenomena-ENSO Role}

The warm phase of the El Niño Southern Oscillation (ENSO) [32], linked to above average precipitation, promotes DF activity in the CA [7,106-108]. The largest event occurred in the Elqui valley took place in 1997 during the most intensive El Niño event [45]. The peak of DFs activity has been documented during the El Niño warm phase in the Mendoza Valley $\left(32^{\circ} \mathrm{S}\right)$ [7]. At least 55 events were exceptionally reported during 29 consecutive days in the 2015/2016 South Hemisphere summer when the GODZILLA event was hitting [12]. In the highest Andean sectors, westerlies intensification during El Niño set off a denser snow precipitation that promotes DFs escalation on the following warmer season [18].

On the western side, the 1993 event on the 2nd and 3rd of May that affected seriously the city of Santiago de Chile was generated by heavy rainfall associated with warm conditions in the troposphere linked to a moderate ENSO event [76]. During this single event, a maximum intensity rainfall of $12 \mathrm{~mm} / \mathrm{h}$ was reported, which is a high value expected only every 25 years [109].

\section{Environmental Impacts}

Large economic losses resulting from unexpected violent DFs have been underestimated in the CA, with the environmental consequences even less considered. In turn, these effects might be important for catchment dynamics.

\subsection{Alteration on Stream Dynamics}

The DFs are generated in valley hillslopes and move downstream, removing material along its path. This clastic and organic material is discharged along alluvial channels, creeks, or streamflows controlling sediment budgets in the catchment $[110,111]$. The sediments mobilization from hillslopes switches further slope erosion, while sediments transferred downstream supply removable material for future flows. This debris material transfer certainly drives basin dynamics.

The DFs provide important sediment loads, and bank undercutting increases its erosion power. This sediment input derivates on changes in geomorphological aspect of 
valleys. As an example, overflows, as a consequence of several DFs channeled in the Blanco Valley $\left(33^{\circ} \mathrm{S}\right)$, were recorded in 1942, 1945, and 1957 . These powerful erosive events caused changes on valley configuration, and bridges and roads were swept away.

\subsection{Effects of Landslide Dams on Streams and Valleys}

The long-term contribution of sediment material forces the progression of alluvial fans toward the main drained streamflow, bringing local channel constriction and riverbed adjustments. Whereas, fast DFs have generated partial or complete river blockages that breed impounded lakes. The Elqui Valley $\left(30^{\circ} \mathrm{S}\right)$ was dammed in two sectors during the Algarrobal DF in 1934 [73]. The Turbio River, upstream in the Elqui Valley, was partly blocked during 2015 [79] (and 2017 events (Table 1)).

The Mendoza River $\left(32^{\circ} \mathrm{S}\right)$ was partially obstructed by the Soltera DF on 7th February 2016. Historical DFs have also obstructed partially the Vacas Valley such as during the events reported in 2004 and 2008 [104].

\subsection{Impact on Ecosystems}

Stream flows with great sediment load may also generate negative effects on the coastal ecosystem. The sediment discharge into the sea should generate a great mortality over banks of filtering organism, such as clams, generating environmental and economic problems. In the Coquimbo region, this issue was really important before the operation of the Puclaro reservoir that was built in 1997.

In addition, streamflow with great sediment load generates troubles in the water treatment process for consumption. Commonly, these sediment-laden flows produce damage to the filters occasioning reduction on drinking water in the Andean communities.

\section{Discussion Concerning Climate Change and Final Remarks}

Until now, precipitation threshold values for triggering DF have been mainly established from total day precipitation, as records of precipitation intensity are lacking in the most catchments of the study area. The occurrence of DFs in the CA is mainly related to rainfall during 1-2 days, thus understanding that the synoptic situation associated with these events may improve prediction and system alerts. A small positive trend in rainfalldriven landslides during summer in the eastern Argentinean piedmont persists since the mid-20th century $\left(32^{\circ} \mathrm{S}\right)$, matching with an increase on Atlantic monsoon precipitation.

Less common events are those related to the release of melt water from the periglacial environment located in the upper sectors of Andean catchments. The warming and ensuing rise of the zero-isotherm in a context of global change will affect these environments, increasing the frequency of DFs. In this sense, the behavior of melt-driven events could vary for the coming decades depending on the type and the water source. The future situation of the DFs triggered from the melt of seasonal snow and ice within the active layer is not clear; on the one hand, the solid precipitation that feeds the seasonal snowpack and active layer will decrease, but on other hand, an increase is expected in the maximum potential melting rate due to the rise in maximum temperatures during the ablation period [78].

Higher temperatures are raising the zero-isotherm elevation; that stimulates permafrost degradation with increased suitable water-saturated areas during rainfall. The intensification of the warm phase of El Niño-ENSO linked to climate change could force the distribution and frequency of DFs as well as their intensity and volume whether ice glacial input is involved.

Overall, the connection between climate change and debris flow occurrence is not fully proved. It is feasible that concentrated episodes of heavy rain may trigger more frequent $\mathrm{DFs}$, even though a decreasing winter precipitation is predict by global models. In the same way, a weakened permafrost and glacier cover might produce more DFs. Long-term data series are needed to establish a causal link with climate, which need to be properly analyzed with statistical methods. As far as we are aware, this kind of analysis has not 
been carried out yet. Records of DFs in the Mendoza river basin show a rising trend in recent decades, but the cause of this pattern is still uncertain. Therefore, this issue is worthy of further research and would be a natural continuation of this line of research in semiarid zones.

Unanswered research inquiries remain about the behavior of the DFs. The role of seismic shaking on debris supply in the DF-generating slopes has been little explored in this active tectonic region. Studies focused on the role of cineritic levels (tephra) as facilitators of DF events are also needed. The consequences of ensuring fires due to the mega-drought on slope behavior are still not known. For example, landslides were induced after the wildfires of California in 2020 [110], and this still has to be studied in the area.

Finally, the most severe and impacting DFs in the CA are those channelized in alluvial creeks that may feed into river streamflow; communities located on alluvial fans will be more vulnerable. Specific geomorphological and hydraulic studies taking care of this alluvial environment dynamics are particularly required to reduce potential damages. Hence, the urgent implementation of mainly structural preventive measures is required based on detailed technical studies. Even though vulnerability assessment is a useful tool on a certain scale, it does not reduce the exposure of Andean communities to risk per se.

Author Contributions: Conceptualization, S.M.M. and S.A.S.; methodology, S.M.M.; software, S.M.M. and M.C.-G.; formal analysis, C.L., S.J.-T., M.C.-G., P.J., I.V. and M.L.; investigation, S.M.M., S.A.S., and J.G.C.; resources, S.M.M., M.C.-G., J.G.C. and M.L.; writing-original draft preparation, S.M.M.; writing-review and editing, S.A.S., J.G.C. M.L., J.L.A.; visualization, S.M.M., M.C.-G., and C.L.; supervision, S.M.M., S.A.S.; project administration, S.M.M., A.M.; funding acquisition, S.M.M., S.A.S., A.M. and J.L.A. All authors have read and agreed to the published version of the manuscript.

Funding: This research was funded by the project 06/ A 711-of the SIIP Secretaría de Investigación, internacionales y postgrado funded by the Universidad Nacional de Cuyo, and the project PIP $11220150100191 \mathrm{CO}$ funded by CONICET. Both projects are leaded by Moreiras. Cooperation research interchanges were done by the framework of the project REDES -180099-CONICYT headed by Maldonado (Chile) and Moreiras (Argentina).

Institutional Review Board Statement: Ethical review and approval were waived for this study because review article do not require follow this type of procedure.

Informed Consent Statement: Not applicable. This study did involve humans.

Data Availability Statement: Data reported in this article are available in published papers and PhD thesis of some authors of this review.

Acknowledgments: We are grateful to Sr Espejo (Uspallata locality, Argentina) and the Dirección Nacional de Vialidad for providing the historical records of the events documented in the Mendoza valley.

Conflicts of Interest: The authors declare no conflict of interest.

\section{References}

1. Hauser, A. Remociones en masa en Chile; Bull. No 59; Servicio Nacional de Geología y Minería: Santiago, Chile, $2000 ;$ p. 75.

2. Valenzuela, L.; Varela, J. El Alfalfal rock fall and debris flow in Chilean Andes Mountains. In Proceedings of the 9th Panamerican Conference on Soil Mechanics and Foundation Engineering, Viña del Mar, Chile, 9-13 December 1991; Volume 1, pp. $357-371$.

3. Espizúa, L.E. Megadeslizamientos pleistocénicos en el valle del río Mendoza, Argentina. In Proceedings of the XVI Congreso Geológico Argentino, La Plata, Argentina, 20-23 September 2005; Volume 3, pp. 477-482.

4. Moreiras, S.M.; Coronato, A. Landslide processes in Argentina. Dev. Earth Surf. Process. 2009, 13, 301-332. [CrossRef]

5. Moreiras, S.M.; Páez, S.M. Historical damages and secondary effects related to intraplate shallow seismicity of Central Western Argentina. Geodynamic Processes in the Andes of Central Chile and Argentina. Geol. Soc. Lond. 2015, 399, 369-382. [CrossRef]

6. Fauqué, L.; Cortés, J.M.; Folguera, A.; Etcheverría, M. Avalanchas de rocas asociadas a neotectónica en el valle del río Mendoza, al sur de Uspallata. Rev. Asoc. Geológica Argent. 2000, 55, 419-423.

7. Moreiras, S.M. Frequency of debris flows and rockfall along the Mendoza river valley (Central Andes), Argentina: Associated risk and future scenario. Quat. Int. 2006, 158, 110-121. [CrossRef]

8. Moreiras, S.M.; Hermanns, R.L.; Fauqué, L. Cosmogenic dating of rock avalanches constraining Quaternary stratigraphy and regional neotectonics in the Argentine Central Andes (32 ${ }^{\circ}$ S). Quat. Sci. Rev. 2015, 112, 45-58. [CrossRef] 
9. Moreiras, S.M. The Plata rock avalanche: Deciphering the occurrence of this huge collapse in a glacial valley of the Central Andes (33 S). Rock Avalanche Front. 2020. [CrossRef]

10. Paez, M.S.; Moreiras, S.M.; Brenning, A.; Giambiagi, L.B. Flujos de detritos-aluviones históricos en la cuenca del Río Blanco $\left(32^{\circ} 55^{\prime}-33^{\circ} 10^{\prime} \mathrm{Y} 69^{\circ} 10^{\prime}-69^{\circ} 25^{\prime}\right)$, Mendoza. Rev. Asoc. Geológica Argent. 2013, 70, 488-498.

11. Sepúlveda, S.A.; Moreiras, S.M.; Lara, M.; Alfaro, A. Debris flows in the Andean ranges of central Chile and Argentina triggered by 2013 summer storms: Characteristics and consequences. Landslides 2015, 12, 115-133. [CrossRef]

12. Moreiras, S.M.; Vergara Dal Pont, I.; Araneo, D. Were merely storm-landslides driven by the 2015-2016 Niño in the Mendoza River valley? Landslides 2018, 15, 997-1014. [CrossRef]

13. Fuenzalida, H.; Aceituno, P.; Falvey, M.; Garreaud, R.D. Estudio de la Variabilidad Climática en Chile para el Siglo XXI: Resumen Ejecutivo; Universidad de Chile: Santiago, Chile, 2006.

14. IPCC. Climate Change 2014: Synthesis Report. Contribution of Working Groups I, II and III to the Fifth Assessment Report of the Intergovernmental Panel on Climate Change; Core Writing Team, Pachauri, R.K., Meyer, L.A., Eds.; IPCC: Geneva, Switzerland, 2014; 151p.

15. Garreaud, R.D.; Alvarez-Garreton, C.; Barichivich, J.; Boisier, J.P.; Christie, D.; Galleguillos, M.; Le-Quesne, C.; McPhee, J.; Zambrano-Bigiarini, M. The 2010-2015 megadrought in central Chile: Impacts on regional hydroclimate and vegetation. Hydrol. Earth Syst. Sci. 2017, 21, 6307-6327. [CrossRef]

16. Garreaud, R.D.; Boisier, J.P.; Rondanelli, R.; Montecinos, A.; Sepúlveda, H.H.; Veloso-Aguila, D. The central Chile mega drought (2010-2018): A climate dynamics perspective. Int. J. Climatol. 2019, 40, 421-439. [CrossRef]

17. Moreiras, S.M. Climatic effect of ENSO associated with landslide occurrence in the Central Andes, Mendoza province, Argentina. Landslides 2005, 2, 53-59. [CrossRef]

18. Moreiras, S.M.; Lisboa, M.S.; Mastrantonio, L. The role of snow melting upon landslides in the central Argentinean Andes. Earth Surf. Process. Landf. 2012, 37, 1106-1119. [CrossRef]

19. Vergara, I.; Moreiras, S.M.; Araneo, D.; Garreaud, R. Geo-climatic hazards in the eastern subtropical Andes: Distribution, Climate Drivers and Trends. Nat. Hazards Earth Syst. Sci. 2020, 20, 1353-1367. [CrossRef]

20. Carrasco, J.F.; Osorio, R.; Casassa, G. Secular trend of the equilibrium-line altitude on the western side of the southern Andes, derived from radiosonde and surface observations. J. Glaciol. 2008, 54, 538-550. [CrossRef]

21. Skermer, N.A.; VanDine, D.F. Debris flows in history. In Debris Flows and Related Phenomena; Jakob, M., Hungr, O., Eds.; Springer: Berlin/Heidelberg, Germany, 2005; Volume 8, pp. 25-51. [CrossRef]

22. Lliboutry, L. Glaciers of the wet Andes. Glaciers S. Am. Satell. Image Atlas Glaciers World 1998, 1386, 1148.

23. Barcaza, G.; Nussbaumer, S.U.; Tapia, G.; Valdés, J.; García, J.L.; Videla, Y.; Amapola, A.; Arias, V. Glacier inventory and recent glacier variations in the Andes of Chile, South America. Ann. Glaciol. 2017, 58 Pt 2, 166-180. [CrossRef]

24. Garreaud, R.D. The Andes climate and weather. Adv. Geosci. 2009, 22, 3-11. [CrossRef]

25. National Oceanic and Atmospheric Administration (NOAA). Available online: https://github.com/cameronleger/goes16background (accessed on 6 November 2020).

26. Compagnucci, R.H.; Agosta, E.A.; Vargas, W.M. Climatic change and quasi-oscillations in central-west Argentina summer precipitation: Main features and coherent behavior with southern African region. Clim. Dyn. 2002, 18, 421-435. [CrossRef]

27. Masiokas, M.H.; Villalba, R.; Luckman, B.H.; Le Quesne, C.; Aravena, J.C. Snowpack variations in the central Andes of Argentina and Chile, 1951-2005: Large-scale atmospheric influences and implications for water resources in the region. J. Clim. 2006, 19, 6334-6352. [CrossRef]

28. Garreaud, R.; Fuenzalida, H. The Influence of Andes on cut off lows: A modeling study. Mon. Wea. Rev. 2007, 135, 1596-1613. [CrossRef]

29. Seluchi, M.E.; Garreaud, R.D.; Norte, F.A.; Saulo, A.C. Influence of the subtropical Andes on baroclinic disturbances: A cold front case study. Mon. Wea. Rev. 2006, 134, 3317-3335. [CrossRef]

30. Viale, M.; Bianchi, E.; Cara, L.; Ruiz, L.; Villalba, R.; Pitte, P.; Masiokas, M.; Rivera, J.; Zalazar, L. Contrasting Climates at Both Sides of the Andes in Argentina and Chile. Front. Environ. Sci. 2019, 7, 69. [CrossRef]

31. Cara, L.; Masiokas, M.; Viale, M.; Villalba, R. Análisis de la cobertura nival de la cuenca superior del río Mendoza a partir de imágenes MODIS. Meteorológica 2016, 41, 21-36.

32. Díaz, H.F.; Kiladis, G.N. Atmosferic teleconnections associated with the extremes phases of Southern Oscillation. In El Niño Historical and Paleoclimatic Aspects of the Southern Oscillation; Diaz, M., Ed.; Cambridge University Press: Cambridge, UK, 1992; pp. 27-28.

33. Montecinos, A.; Díaz, A.; Aceituno, P. Seasonal Diagnostic and Predictability of Rainfall in Subtropical South America Based on Tropical Pacific SST. J. Clim. 2000, 13, 746-758. [CrossRef]

34. Agosta, E.A.; Compagnucci, R.H. Central-West Argentina summer precipitation variability and atmospheric teleconnections. J. Clim. 2012, 25, 1657-1677. [CrossRef]

35. Rivera, J.A.; Arnould, G. Evaluation of the ability of CMIP6 models to simulate precipitation over Southwestern South America: Climatic features and long-term trends (1901-2014). Atmos. Res. 2020, 104953. [CrossRef]

36. Zazulie, N.; Rusticucci, M.; Raga, G.B. Regional climate of the subtropical central Andes using high-resolution CMIP5 modelspart I: Past performance (1980-2005). Clim. Dyn. 2017, 49, 3937-3957. [CrossRef]

37. González, M.E.; Gómez-González, S.; Lara, A.; Garreaud, R.; Díaz-Hormazábal, I. The 2010-2015 Megadrought and its influence on the fire regime in central and south central Chile. Ecosphere 2018, 9, e02300. [CrossRef] 
38. NASA Earth Observatory (18 April 2019) Long-Term Drought Parches Chile. Available online: https:/ / earthobservatory.nasa. gov/images/145874/long-term-drought-parches-chile (accessed on 20 October 2020).

39. Moreiras, S.M. Análisis estadístico probabilístico de las variables que condicionan la inestabilidad de las laderas en los valles de los ríos Las Cuevas y Mendoza. Rev. Asoc. Geológica Argent. 2009, 65, 780-790.

40. Junquera-Torrado, S.; Moreiras, S.M.; Sepúlveda, S.A. Huge Slope Collapses Flashing the Andean Active Orogenic Front (Argentinean Precordillera 31-33 S). In Workshop on World Landslide Forum; Springer: Berlin/Heidelberg, Germany, 2017; pp. 535-541.

41. Junquera-Torrado, S.; Moreiras, S.M.; Sepúlveda, S.A. Distribution of landslides along the Andean active orogenic front (Argentinean Precordillera 31-33 S). Quat. Int. 2019, 512, 18-34. [CrossRef]

42. Drewes, J.; Moreiras, S.M.; Korup, O. Permafrost activity and atmospheric warming in the Argentinian Andes. Geomorphology 2018, 323, 13-24. [CrossRef]

43. Vich, A.; Pedrani, A. (Eds.) Programa de Investigación y Desarrollo: Manejo Ecológico del Piedemonte. Mendoza: Ministerio de Medio Ambiente Urbanismo y Vivienda-CRICYT; Unidad de manejo Ecológico de Cuencas: Mendoza, Argentina, 1993.

44. Mikkan, R.A. Fenómenos Catastróficos Naturales que Afectan al Gran Mendoza. Ph.D. Thesis, Universidad Nacional de Cuyo, Mendoza, Argentina, 1996.

45. Pérez, C.; Fiebig-Wittmaack, M.; Cepeda, J.; Pizarro-Araya, J. Capítulo 8. Desastres Naturales y Plagas en el valle del Río Elqui. In Los Sistemas Naturales de la Cuenca del Río Elqui (Región de Coquimbo, Chile): Vulnerabilidad y Cambio del Clima; Cepeda, P.J., Ed.; Ediciones Universidad de La Serena: La Serena, Chile, 2008; pp. 295-333.

46. Sepúlveda, S.A.; Padilla, C. Rain-induced debris and mudflow triggering factors assessment in the Santiago cordilleran foothills, Central Chile. Nat. Hazards 2008, 47, 201-215. [CrossRef]

47. Hungr, O. Classification and terminology. In Debris Flows and Related Phenomena; Jakob, M., Hungr, O., Eds.; Springer: Berlin/Heidelberg, Germany, 2005; Volume 8, pp. 9-24.

48. Iverson, R.M. Debris-flow mechanics. In Debris-Flow Hazards and Related Phenomena; Jakob, M., Hungr, O., Eds.; Springer: Berlin/Heidelberg, Germany, 2005; Volume 8, pp. 105-134.

49. Costa, J.E. Physical geomorphology of debris flows. In Developments and Applications of Geomorphology; Costa, J.E., Fleisher, P.J., Eds.; Springer: Berlin/Heidelberg, Germany, 1984; pp. 268-317. [CrossRef]

50. Pierson, T.C. Hyperconcentrated flow-transitional process between water flow and debris flow. In Debris Flows and Related Phenomena; Jakob, M., Hungr, O., Eds.; Springer: Berlin/Heidelberg, Germany, 2005; Volume 8, pp. 159-196. [CrossRef]

51. Beverage, J.P.; Culbertson, J.K. Hyperconcentrations of suspended sediment. J. Hydraul. Div. ASCE 1964, 90, 117-128.

52. Hutchinson, J.N. General report: Morphological and geotechnical parameters of landslides in relation to geology and hydrology. In Proceedings of Fifth International Symposium on Landslides; Bonnard, C., Ed.; A.A. Balkema: Rotterdam, The Netherland, 1988; Volume 1, pp. 3-35.

53. Correas-Gonzalez, M.; Moreiras, S.M.; Jomelli, V.; Arnaud-Fassetta, G. Ice-dammed lake outburst flood risk in the Plomo basin, Central Andes (33o S): Perspectives from historical events. Cuad. Investig. Geográfica 2020, 46, 223-249. [CrossRef]

54. King, W.D.V.O. The Mendoza River Flood of 10-11 January 1934-Argentina. Geogr. J. 1934, 321-326. [CrossRef]

55. Prieto, M.d.R. The glacier dam on the Rio Plomo: A cyclic phenomenon? Z. Für Gletsch. Und Glazialgeol. 1986, $22,73-78$.

56. Bruce, R.H.; Cabrera, G.A.; Leiva, J.C.; Lenzano, L.E. The 1985 surge and ice dam of Glaciar Grande del Nevado del Plomo, Argentina. J. Glaciol. 1987, 33, 131-132. [CrossRef]

57. D'Odorico-Benites, P.E.; Pérez, D.J.; Sequeira, N.; Fauqué, L. El Represamiento y aluvión del Río Santa Cruz, Andes Principales $\left(31^{\circ} 40^{\prime}\right.$ S), Provincia de San Juan. Rev. Asoc. Geológica Argent. 2009, 65, 713-724.

58. Perucca, L.P.; Esper-Angillieri, Y. El deslizamiento de rocas y detritos sobre el río Santa Cruz y el aluvión resultante por el colapso del dique natural, Andes Centrales de San Juan. Rev. Asoc. Geológica Argent. 2009, 65, 571-585.

59. Penna, I.M.; Derron, M.H.; Volpi, M.; Jaboyedoff, M. Analysis of past and future dam formation and failure in the Santa Cruz River (San Juan province, Argentina). Geomorphology 2013, 186, 28-38. [CrossRef]

60. Breien, H.; De Blasio, F.V.; Elverhøi, A.; Høeg, K. Erosion and morphology of a debris flow caused by a glacial lake outburst flood, Western Norway. Landslides 2008, 5, 271-280. [CrossRef]

61. Miers, J. Travels in Chile and La Plata: Including Accounts Respecting the Geography, Geology, Statistics, Government, Finances, Agriculture, Manners, and Customs, and the Mining Operations in Chile; Baldwin, Cradock and Joy: London, UK, 1826.

62. Brandt, C. Journal of a Voyage a Passage across the Cordillera de los Andes in the Winter of 1827; Henry Colburn Editions: London, UK, 1828.

63. Forbes, D. Informe Sobre el Terremoto de Mendoza; Revista de la Junta de Estudios Históricos de Mendoza, 10 Primera Época); RJEHM: Mendoza, Argentina, 1938; pp. 111-120.

64. Lemos, A. Apuntes de un viaje de Mendoza a Valparaiso; Impresiones del El Ferrocarril: Mendoza, Argentina, 1884.

65. Proctor, R. Narraciones del viaje por la Cordillera de los Andes y Residencia de Lima y otras Partes del Perú en los años 1823 y 1824 (La Cultura Argentina); Vaccaro: Buenos Aires, Argentina, 1920.

66. Kittl, E. Derrumbamientos, Deslizamientos y Torrentes en Caminos de Montaña de la República Argentina; Publicaciones Serie B (Cientifico-Tecnológica); Facultad de Ciencias Exactas y Naturales, Universidad de Buenos Aires: Buenos Aires, Argentina, 1939; Volume 16, pp. 3-111.

67. Coleman, A.H. Mi Vida de Ferroviario Inglés en la Argentina 1887-1948; Universidad Nacional del Sur Ed: Bahía Blanca, Argentina, $1949 ;$ p. 701. 
68. RJEHM. Revista de Junta de Estudios históricos de Mendoza; Segunda etapa, N 11; RJEHM: Mendoza, Argentina, 1987.

69. Moreiras, S.M. Landslide incidence zonation in the Rio Mendoza valley, Mendoza province, Argentina. Earth Surf. Process. Landf. 2004, 29, 255-266. [CrossRef]

70. Verdaguer, J.A. Historia eclesiástica de Cuyo. Premiat. Sc. Tipográfica Sales. Milán 1929, Tomo II, 415-425.

71. Urrutia de Hazbún, R.; Lanza Lazcano, C. Catástrofes en Chile 1541-1992; Editorial La Noria: Santiago, Chile, 1993.

72. Pérez, C. Cambio Climático: Vulnerabilidad, Adaptación y rol Institucional: Estudios de caso en el valle de Elqui. Master's Thesis, Universidad de La Serena, La Serena, Chile, 2005.

73. Graña-Pezoa, F. Crónicas y Recuerdos de una Inundación en el Valle del Elqui. 2007; Unpublished work.

74. Sernageomin, Principales Desastres Ocurridos Desde 1980 en Chile. Available online: http://sitiohistorico.sernageomin.cl/pdf/ presentaciones-geo/Primer-Catastro-Nacional-Desastres-Naturales.pdf (accessed on 4 November 2020).

75. Garviso, E. Seremi de Agricultura no Tiene Disposición a Servir y no cree en los Actores Privados. El Día, 4 May 2004; 11-13.

76. Hauser, A. Rock avalanche and resulting debris flow in Estero Parraguirre and Río Colorado, Región Metropolitana, Chile. In Catastrophic Landslides: Effects, Occurrence and Mechanisms. Reviews in Engineering Geology; Evans, S.G., Degraff, J.V., Eds.; Geological Society of America: Boulder, CO, USA, 2002; Volume XV, pp. 135-148.

77. Casassa, G.; Marangunic, C. The 1987 Río Colorado rockslide and debris flow, central Andes, Chile. Bull. Assoc. Eng. Geol. 1993, 30, 321-330. [CrossRef]

78. Vergara Dal Pont, I.; Moreiras, S.M.; Santibañez, F.; Araneo, D.; Ferrando, F. Debris flows triggered from melt of seasonal snow and ice within the active layer in the semi-arid Andes. Permafr. Periglac. Process. 2020, 31, 57-68. [CrossRef]

79. Vergara Dal Pont, I.; Santibañez, F.; Araneo, D.; Ferrando, F.; Moreiras, S. Determination of probabilities for the generation of high-discharge flows in the middle basin of Elqui River, Chile. Nat. Hazards 2018, 93, 531-546. [CrossRef]

80. Sepúlveda, S.A.; Rebolledo, S.; Vargas, G. Recent catastrophic debris flows in Chile: Geological hazard, climatic relationships and human response. Quat. Int. 2006, 158, 83-95. [CrossRef]

81. Moyano, R.J.; Rubio, C. Génesis y características de un nuevo flujo de detritos en Lo Valdés, Cajón del Maipo, Chile. Nadir Rev. Electron. Geogr. Austral 2011, 3, 1.

82. Peña-Torrealba, H.; Klohn, W. Hidrología de desastres en Chile. Crecidas catastróficas recientes de origen no meteorológico. Rev. Soc. Chil. Ing. Hidráulica 1990, 5. Available online: http:/ / 164.77.211.36/ipac20/ipac.jsp?session=G513HF4632305.1786409 \&profile $=$ cirh\&uri=full\%3D3100001\%7E\%214008\%7E\%210\&booklistformat= (accessed on 3 November 2020).

83. Rojas, O.; Mardones, M.; Arumí, J.L.; Aguayo, M. Una revisión de inundaciones fluviales en Chile, período 1574-2012: Causas, recurrencia y efectos geográficos. Rev. Geogr. Norte Gd. 2014, 57, 177-192. [CrossRef]

84. Wick, E.; Baumann, V.; Favre-Bulle, G.; Jaboyedoff, M.; Loye, A.; Marengo, H.; Rosas, M. Flujos de detritos recientes en la cordillera frontal de Mendoza: Un ejemplo de riesgo natural en la ruta 7. Rev. Asoc. Geológica Argent. 2010, 66, 460-465.

85. Departamento General de Irrigación. Press Release. Available online: https://www.mendoza.gov.ar/prensa/irrigacion-solicitaa-vecinos-de-la-zona-de-potrerilos-que-realicen-un-uso-restringido-del-agua/ (accessed on 3 November 2020).

86. Lauro, C.; Moreiras, S.M.; Junquera, S.; Vergara, I.; Toural, R.; Wolf, J.; Tutzer, R. Summer rainstorm associated with a debris flow in the Amarilla gully affecting the international Agua Negra Pass ( $30^{\circ} 20^{\prime}$ S), Argentina. Environ. Earth Sci. 2017, 76, 213. [CrossRef]

87. Polanski, J. Flujos Rápidos de Escombros Rocosos en zonas áridas y Volcánicas; EUDEBA (Universitaria de Buenos Aires): Buenos Aires, Argentina, 1966; p. 67.

88. Sepúlveda, S.A. Methodology for debris flow hazard evaluation in mountainous environments. Comunicaciones 2000, 51, 3-18.

89. Ravazzolo, D.; Mao, L.; Mazzorana, B.; Ruiz-Villanueva, V. Brief communication: The curious case of the large wood-laden flow event in the Pocuro stream (Chile). Nat. Hazards Earth Syst. Sci. 2017, 17, 2053-2058. [CrossRef]

90. Naranjo, J.A.; Varela, J. Flujos de Detritos y barro que Afectaron el Sector Oriente de Santiago, el 3 de mayo de 1993 (No. 47 ); Servicio Nacional de Geología y Minería: Santiago, Chile, 1996.

91. Jeanneret, P.; Moreiras, S.M. Inventario de procesos de remoción en masa en la cuenca baja del Río Blanco ( $\left.31^{\circ} \mathrm{S}\right)$, Andes Centrales Argentinos. Rev. Mex. Cienc. Geológicas 2018, 35, 215-227. [CrossRef]

92. Álvarez, M.A.; Mastrantonio, L.; Moreiras, S.M. Susceptibilidad a la ocurrencia de flujos de detritos a escala regional en el Parque Provincial Aconcagua, Mendoza, Argentina. Rev. Fac. Agrar. 2019, 51, 177-191. Available online: http:/ / revistas.uncu.edu.ar/ ojs/index.php/RFCA/article/view/2620 (accessed on 15 October 2020).

93. Tapia Baldis, C.; Trombotto Liaudat, D. Rockslides and rock avalanches in the Central Andes of Argentina and their possible association with permafrost degradation. Permafr. Periglac. Process. 2019, 30, 330-347. [CrossRef]

94. Moreiras, S.M.; Jeanneret, P.; Lauro, C.; Vergara Dal Pont, I. Correas Gonzalez M y Junquera Torrado, S. Deslizamientos asociados a la degradación del permafrost: Evidencias geomorfológicas en el pasado y presente en los Andes Centrales (31 $\left.1^{\circ}-34^{\circ} \mathrm{S}\right)$. Rev. Uerjde Univ. Estado Jan. Bras. Edición Espec. Geógrafos Hisp. 2019, 35, 45036. [CrossRef]

95. Moreiras, S.M.; Jeanneret, P.; Junquera Torrado, S.; Correas Gonzalez, M.; Moragues, S. Grandes colapsos de laderas asociados a la deglaciación pleistocena en los Andes Centrales de Argentina. Rev. Asoc. Geológica Argent. 2020, 77, 91-103.

96. Moreiras, S.M. Zonificación de Peligrosidad y de Riesgo de Procesos de Remoción en Masa en el Valle del río Mendoza. Provincia de Mendoza. Ph.D. Thesis, Facultad de Ciencias Exactas, Fisicas y Naturales, Universidad de San Juan, San Juan, Argentina, 2004.

97. Santos, J.; Norte, F.; Moreiras, S.M.; Araneo, D.; Simonelli, S. Prediccion de episodios de precipitación que ocasionan aludes en el área montañosa del noroeste de la provincia de Mendoza, argentina. GEOACTA 2015, 40, 65-75. 
98. Esper Angillieri, M.Y. El Aluvión del 13 de Febrero de 1944 en la Quebrada del Carrizal, Departamento Iglesia, Provincia de San Juan. Rev. Asoc. Geológica Argent. 2007, 62, 283-288.

99. Hauser, A. Flujos de barro en la zona preandina de la Región Metropolitana: Características, causas, efectos, riesgos y medidas preventivas. Rev. Geológica Chile 1985, 24, 75-92.

100. Lavigne, F.; Suwa, H. Contrasts between debris flows, hyperconcentrated flows and stream flows at a channel of Mount Semeru, East Java, Indonesia. Geomorphology 2004, 61, 41-58. [CrossRef]

101. Lara, P. Caracterización Hidrológica de las Corrientes de Detritos en Chile Central. Master's Thesis, Department of Civil Engineering, University of Chile, Santiago, Chile, 1996.

102. Harris, I.; Jones, P.D.; Osborna, T.J.; Listera, D.H. Updated high-resolution grids of monthly climatic observations-the CRU TS3.10 Dataset. Int. J. Climatol. 2014, 34, 623-642. [CrossRef]

103. Hauser, A. Evaluación de Vulnerabilidad y Propuesta de Procedimientos para el Control de flujos Detríticos o Aluvionales en Segmento Juncal-Portillo, del Camino Internacional a la República Argentina; Servicio Nacional de Geología y Minería: Santiago, Chile, 2005.

104. Moreiras, S.M.; Lenzano, M.G.; Riveros, N. Inventario de procesos de remoción en masa en el Parque Provincial Aconcagua, provincia de Mendoza-Argentina. Multequina 2008, 17, 129-146.

105. Brenning, A. Geomorphological, hydrological and climatic significance of rock glaciers in the Andes of Central Chile (33-35 S). Permafr. Periglac. Process. 2005, 16, 231-240. [CrossRef]

106. Mergili, M.; Marchant, C.; Moreiras, S.M. Causas, características e impacto de los procesos de remoción en masa, en áreas contrastantes de la región Andina. Cuad. Geogr. Rev. Colomb. Geogr. 2015, 24, 113-131. [CrossRef]

107. Aguilar, G.; Cabré, A.; Guaita, C.; González, F.; Ortega-Culaciati, F.; Carretier, S.; Riquelme, R.; Comte, D. Denudación por flujos de detritos duran te las lluvias torrenciales de Marzo de 2015 en Atacama. In Proceedings of the XIV Congreso Geológico Chileno, La Serena, Chile, 4-8 October 2015.

108. Moreiras, S.M.; Sepúlveda, S.A. Megalandslides in the Andes of central Chile and Argentina $\left(32^{\circ}-34^{\circ} \mathrm{S}\right)$ and potential hazards. Geol. Soc. Lond. Spec. Publ. 2015, 399, 329-344. [CrossRef]

109. Garreaud, R.; Rutllant, J. Meteorological analysis of debris flow in Antofagasta and Santiago de Chile during 1991-1993. ATMOSFERA 1996, 9, 251-271.

110. Benda, L.; Dunne, T. Erosion and Sedimentation in the Pacific Rim. In Proceedings of the Corvallis Symposium, Corvallis, OR, USA, 3-7 August 1987.

111. Rengers, F.K.; McGuire, L.A.; Oakley, N.S.; Kean, J.W.; Staley, D.M.; Tang, H. Landslides after wildfire: Initiation, magnitude, and mobility. Landslides 2020, 17, 2631-2641. [CrossRef] 